\title{
FATORES INTERVENIENTES DA COMPETITIVIDADE DAS EXPORTAÇÕES BRASILEIRAS COM ÊNFASE NA DESONERAÇÃO TRIBUTÁRIA
}

\author{
Luiz Henrique da Silva Freitas \\ Graduado em Tecnologia em Comércio Exterior pelo Instituto Federal de Educação, \\ Ciência e Tecnologia do Rio Grande do Norte - IFRN. E-mail: luiz_lh214@ hotmail.com \\ Elisângela Cabral de Meireles \\ Graduada em Ciências Econômicas-UFRN, esp. em Economia Regional, Comércio \\ Exterior e Globalização-UFRN, mestre em Administração (Gestão e Políticas Públicas) \\ UFRN , Professora do IFRN (Comércio Exterior e Economia) e Professora Orientadora da \\ Base de Pesquisa “Análise do Mercado Exportador do Rio Grande do Norte (IFRN). \\ E-mail- elisangela@cefetrn.br
}

\section{RESUMO}

Uma vez averiguada a onerosa carga tributária nacional e verificada a existência da política de desoneração fiscal na exportação, objetivando aumentar a competitividade do produto nacional no exterior, buscou-se nesse trabalho, observar a sistemática de desoneração fiscal brasileira, bem como o processo de formação de preço do produto a ser exportado, por meio de uma pesquisa descritiva elaborada através de levantamentos doutrinários, bibliográficos e de fontes secundárias. Reconhece-se, destarte, a importância das exportações nacionais ao desenvolvimento da economia nacional gerando uma série de benefícios à nação. Procurou-se, dessa forma, verificar as variáveis internas e externas, limitantes e estimuladoras que interferem no processo de formação de preço do produto e, consequentemente, na competitividade do produto nacional brasileiro no mercado externo. Ao analisar tais objetos de pesquisa, chegou-se à conclusão que o sistema de desoneração tributária brasileira é ineficiente, e que existe uma série de fatores intervenientes no processo de formação de preço que o impede de ser enquadrado em uma simples fórmula matemática. Sugeriu-se mudanças no sistema tributário brasileiro, de forma a torná-lo eficiente, desburocratizando os seus processos e mecanismos e diminuindo a carga tributária nacional, a fim de estimular o desenvolvimento econômico pátria. Apontou-se também a importância do profissional da área de comércio exterior, para guiar a empresa a um processo de internacionalização sustentável e exitoso.

PALAVRAS-CHAVE: Exportações Brasileiras. Direito Tributário. Desoneração Tributária nas Exportações. Formação de Preço. Competitividade.

\begin{abstract}
Once verified the heavy taxes applied nation-wide and the existence of tax-lowering politics at the exporting process, seeking to achieve higher competition levels for the national product in the international commerce, this research intends to observe the Brazilian tax-lowering systematic and also the price-building process for the product which will be exported trough bibliographic and secondary sources research. Therefore, it notices the importance of national exports to the local economy development which brings many benefits to the nation. Inner and outer variables that could be limiting or stimulating have been verified in order to examine whether they interfere at the price-building process as
\end{abstract}


well as in the Brazilian product competition in the international market. After an analyses process, it has been concluded that the Brazilian tax-lowering system is inefficient and that there are many other factors acting in the price-building process, that makes the use of a simple mathematic formula impossible. This work suggests changes in the national tributary system as a way to make it efficient and lead to less bureaucracy in its processes and mechanisms as well as a lower tribute rate, contributing to national development. The work also points to the importance of the international commerce area professional to lead the company to a sustainable and successful internationalization.

KEY-WORDS: Brazilian Exports. Tributary Law. Tax-Lowering Politics in Exports. Price-Building. Competitivity. 


\section{FATORES INTERVENIENTES DA COMPETITIVIDADE DAS EXPORTAÇÕES BRASILEIRAS COM ÊNFASE NA DESONERAÇÃO TRIBUTÁRIA}

\section{INTRODUÇÃO}

A humanidade chega a um estágio de desenvolvimento em que os diversos povos estão cada vez mais integrados, seja no aspecto econômico, social, cultural e político. Os grandes avanços dos meios de transporte e de comunicação fazem com que o mundo se aproxime, as distâncias diminuam e haja uma maior interação entre as nações.

Esse processo de globalização possibilita a expansão do capitalismo, se tornando, de acordo com Santos (2008), o ápice do processo de internacionalização do mundo capitalista, no qual os negócios se expandem para mercados muitas vezes distantes e emergentes, sem necessariamente requerer um grande investimento financeiro, pois os já citados avanços tecnológicos, da comunicação e dos meios de transporte, possibilitam essa diversificação na atuação de mercado, aumentando, assim, a concorrência. Fala-se, então, em um mercado global.

Ao analisar a concorrência no mercado global, tem-se que lembrar um importante fator para a subsistência de qualquer empresa em atividade é a sua competitividade, ou seja, em termos microeconômicos, de acordo com Chudnovsky (1990), a aptidão de êxito de uma firma no projeto, produção e venda de um determinado produto em relação aos seus concorrentes.

Além disso, deve-se notar que no atual estágio da expansão capitalista, e, portanto, no atual comércio exterior, o mercado é demasiadamente amplo, devendo a empresa observar não só a concorrência do mercado interno onde atua, mas toda a concorrência mundial, que com o advento da globalização, acaba por influenciar, participar e atuar nos diversos mercados.

Nesse contexto, o comércio exterior é uma realidade para os diversos tipos de empresa e de países. Dessa maneira, as empresas buscam na internacionalização dos seus produtos as vantagens da exportação. Essas vantagens, de acordo com Keedi (2008), em linhas gerais são: a diversificação de mercados, o aumento da produtividade, aperfeiçoamento da qualidade do produto, diminuição da carga tributária e melhoria da imagem da empresa.

Segundo o mesmo autor, com a diversificação de mercados, diversificam-se os riscos (e a dependência da empresa aos riscos inerentes do mercado interno, como a redução de preço, de consumo, mudanças de hábitos e políticas governamentais) e aumenta-se o consumo do produto.

Ainda na mesma obra, observa-se que o acréscimo da produtividade implica, conseqüentemente, no crescimento do emprego, resultando em mais salário disponível na economia, majorando, assim, o poder de consumo da sua população e impulsionando a economia nacional.

Nessa linha de raciocínio, o crescimento da produção aumentará, também, a competitividade, pela redução dos custos fixos, diluídos pela economia de escala, bem 
como fornecerá uma maior capacidade de negociação junto ao fornecedor de matériasprimas.

Como na exportação a exigência por produtos melhor elaborados para o atendimento de mercados exigentes é maior, o país exportador ganha com o aprimoramento dos recursos humanos e tecnológicos. Assim, temos como efeitos diretos da internacionalização dos produtos o reconhecimento da empresa como produtora de bens para o mercado internacional, bem como o fortalecimento de sua marca.

Para aumentar a competitividade dos produtos no mercado internacional, e permitir a competição em favoráveis condições de preço, tende-se a diminuir a carga tributária, incentivando os produtos que se destinam ao mercado internacional.

Para Castro (2007), esses incentivos fiscais à exportação são comuns aos principais países exportadores e foram concedidos de acordo com as normas técnicas definidas no Acordo Geral de Tarifas e Comércio (GATT) e confirmados pela Organização Mundial de Comércio (OMC).

O Brasil desonera os seguintes tributos, na exportação: Imposto sobre Produto Industrializado (IPI), Imposto sobre Operação de Circulação de Mercadorias e de Prestação de Serviços de Comunicação e de Transporte Interestadual e Intermunicipal (ICMS), Programa de Integração Social (PIS) e Contribuição para o Financiamento da Seguridade Social (COFINS).

Com isso, a desoneração dos tributos supracitados na exportação serve como incentivo fiscal para aumentar a competitividade dos produtos nacionais no mercado externo, no contexto da globalização e para estimular a exportação brasileira, para assim gozar dos benefícios provenientes da mesma.

No que concerne à justificativa da presente pesquisa, é notória a grande carga tributária incidente na economia brasileira. Nestes termos, toda e qualquer contribuição no intuito de viabilizar maiores condições de competição no mercado é extremamente válida e o tema da desoneração fiscal na exportação se mostra peculiarmente interessante, visto que abrange questões cruciais de estudo: exportação de produtos, o tratamento tributário das operações de exportação e as suas consequências como elementos intervenientes na competitividade dos produtos brasileiros no exterior.

Academicamente, embora já se observe alguns autores explorarem esse ponto nevrálgico, não se encontra foco específico nessa relação, tampouco considerações realizadas sobre o tema, como o trabalho se propõe a fazer, além de atualizar as constantes alterações das normas que regem tais assuntos. Neste sentido, torna-se manifesta a relevância da pesquisa nesse meio.

No tocante à importância sócio-econômica, a contribuição do estudo é explicita quando considera-se a quantidade de empresas que se inserem no comércio internacional, ou estão buscando a sua inserção. Ora, um estudo que procura esclarecer os aspectos competitivos dessas empresas beneficia todos os envolvidos no empreendimento da exportação, estimulando a sua ação sustentável e acarretando os seus benefícios, quais sejam: geração de emprego, renda, trabalho e desenvolvimento econômico. 
Para o pesquisador, a problemática do tratamento tributário no comércio exterior sempre se mostrou interessante. Neste sentido, a necessidade de formulação de pesquisa de estratégias para o uso de tal ferramenta, ampliando a competitividade dos produtos no mercado internacional e aliada ao tema central do curso de Tecnologia em Comércio Exterior surgiu naturalmente e culminou na confecção deste trabalho.

Dessa maneira, o trabalho busca elucidar e discorrer acerca do tratamento tributário que é dado às exportações brasileiras e abalizar os resultados provenientes desse incentivo analisando os fatores de interveniência na competitividade brasileira, no mercado externo.

Sem sombras de dúvidas, um dos grandes problemas nacionais é a onerosa carga tributária, que contribui para que o Brasil tenha indicadores econômicos menores do que os almejados pelo governo, haja vista o atual cenário econômico favorável ao crescimento econômico da país como a inflação sob controle, juros em queda e o mercado interno em plena reação. (BRAZIL EXPORT, 2009)

De acordo com a Receita Federal, em 2008, a arrecadação estatal alcançou recorde, quando a carga tributária atingiu o patamar de $35,8 \%$ do PIB, soma de todas as riquezas produzidas no Brasil, o que se traduz em valores nominais na ordem de $\mathrm{R} \$ 1.034,40$ milhões. (BRASIL, 2008b)

$\mathrm{Na}$ revista especializada em comércio exterior Brazil Export (2009) está destacada a onerosa carga tributária brasileira, que aumenta o preço dos produtos no país, tornando-os menos competitivos no mercado externo, diminuindo a capacidade de investimento das empresas, reduzindo lucros, desestimulando a criação de novos empregos e encorajando a sonegação de impostos.

Conforme Castro (2007), com a desoneração dos impostos nas operações de exportação, o peso dessa carga tributária diminui, tornando os produtos mais competitivos sob o aspecto do preço. Essa competitividade é importantíssima no atual cenário de concorrência internacional.

Assim, quando um exportador planejar a comercialização para o exterior, ele irá formular o preço do produto final, baseado entre outros fatores, na desoneração fiscal, ou seja, nos incentivos tributários. Esses incentivos fazem com que, por vezes, o produto no mercado externo tenha um preço mais competitivo do que no próprio mercado interno.

Analisando essa discussão e aspectos intervenientes apresentados, surge espaço para a seguinte problemática de pesquisa: como o cenário do incentivo fiscal na exportação impacta sobre a competitividade dos produtos brasileiros no comércio exterior?

No tocante aos objetivos, em âmbito geral espera-se compreender a dinâmica econômica da desoneração tributária nas operações de exportação brasileiras. Em âmbito específico, procura-se identificar a carga tributária incidente nas operações comerciais de exportação; analisar os fatores intervenientes no processo de formação de preço de exportação, levando como base a desoneração da exportação brasileira.

Em se tratando de base metodológica, de acordo com Maia e Oliveira (2005), a pesquisa descritiva é a caracterização do fenômeno estudado, onde serão descritas suas características, suas variáveis e as relações entre elas. 
O trabalho se caracteriza, então, como uma pesquisa exploratório-descritiva, uma vez que busca estudar e descrever o fenômeno da desoneração fiscal da exportação. Assim, por meio de um levantamento doutrinário e bibliográfico, haverá a coleta das informações referentes aos tributos incidentes e não incidentes nas operações de exportação, como também de assuntos referentes à formação do preço de exportação dos produtos brasileiros, de modo a analisar a competitividade do produto brasileiro no mercado externo.

A fonte de pesquisa, conforme Gil (2002), por ser doutrinária e bibliográfica, é composta por vários documentos dos assuntos afins ao trabalho, analisando sempre as autoridades no assunto. São documentos como: artigos de revista especializados, artigos da internet, websites, artigos de jornais locais e regionais, artigos científicos, monografias e livros, que sustentarão a base da pesquisa.

Além dos dados qualitativos, que buscam a estruturação teórica do trabalho, utilizar-se-á dados quantitativos, auxiliados pela estatística descritiva e seus instrumentos, para a melhor apreensão do contexto e do conteúdo trabalhado.

Assim, a pesquisa trabalhará com um contexto nacional do tratamento fiscal exportador, buscando estar adequadamente embasada e fundamentada para o referido estudo, podendo servir a posteriori como modelo de estratégia de tomada de decisão para empresas que atuem no mercado internacional, ou tencionem atuar.

O trabalho está seccionado em quatro capítulos a destacar no primeiro tópico os aspectos gerais da formação de preço. O segundo capítulo trata do referencial teórico do Direito Tributário estabelecendo seus princípios norteadores, as espécies tributárias e as classificações doutrinárias dos tributos.

O terceiro tópico trata da relação entre direito tributário e o comércio exterior brasileiro, no qual se analisa o atual estágio do comércio exterior brasileiro e o relaciona com os incentivos do direito tributário às exportações brasileiras.

O quarto capítulo realizará a análise do tratamento tributário e de outros elementos, como despesas exclusivamente internas e despesas exclusivamente externas, como fator interveniente na competitividade nacional. Espera-se, dessa forma, alcançar os objetivos propostos.

\section{O PROCESSO DE FORMAÇÃO DE PREÇO PARA A EXPORTAÇÃO}

A determinação do preço de exportação é um dos aspectos mais importantes e decisivos no processo de internacionalização de empresas, pois representa importante reflexo na estratégia de atuação e manutenção da empresa no mercado externo. Ela exige conhecimento pleno da estrutura de custos.

A competitividade do produto no mercado internacional também depende fundamentalmente do preço estipulado. O preço é elemento decisivo porque define uma condição básica para a realização de negócio. Já o maior fator motivacional para a participação no mercado externo é a obtenção de lucros esperados. Tem-se, então, de acordo com Lopez (2007), o conflito entre o preço atrativo para o consumidor e a maximização do lucro para a empresa. 
Historicamente, segundo o mesmo autor, houve época em que se podia praticar o preço mais alto possível, desde que não malograsse a venda. Hodiernamente, em face do processo acentuado de internacionalização da economia e a acirrada concorrência resultante, os preços são reduzidos o tanto necessário para a manutenção da competitividade, desde que reste algum lucro. Existem até casos de vendas com prejuízos no curto prazo, em prol de preservar a fidelidade comercial.

Conhecer os custos da empresa e o ambiente em que ela está inserida é fundamental para a formação do preço de exportação, visto que não se sabe o grau de influência que determinado fator, interno ou externo, irá afetar no custo final do produto da empresa. Um erro quanto ao processo de formação preço do produto no mercado externo pode retirar a sua competitividade no mercado internacional e inviabilizar a tomada de decisão correta e segura sobre o preço.

Portanto, para avaliar se uma operação de comércio exterior é vantajosa, cabe identificar os custos incidentes sobre toda a operação, bem como levantar os incentivos e benefícios disponíveis nos mercados vendedores e compradores, de modo a precificar competitivamente os produtos da empresa.

\section{ENGENHARIA DE PREÇOS}

Minervini (2008) se refere ao processo de formação de preço como uma espécie de engenharia de preço, que são instrumentos de aumento de competitividade, como: a seleção de um parceiro adequado; a programação de compras; a classificação alfandegária correta do produto; o conhecimento e utilização dos acordos internacionais existentes; utilização de zonas francas e zonas especiais de exportação; a procura da melhor logística (embalagem, transporte e design) e dos incoterms mais apropriados.

Autores a exemplo de Minervini (2008), Lopez (2007) e Castro (2007) destacam a importância de conhecerem-se todas as peculiaridades que irão afetar na comercialização do produto no mercado internacional. Dessa forma, Lopez (2007) e Castro (2007), convergem a três elementos essenciais para o processo de formação de preço: a estrutura dos custos internos ou os gastos normais à produção e comercialização do produto, o conhecimento dos mercados externos e as suas inúmeras variáveis e o poder de percepção e síntese do negociador da empresa.

O primeiro elemento, o levantamento dos componentes que geram gastos, é fundamental na montagem do cenário da formação de preço, qualquer que seja o enfoque. Definir a estrutura dos custos internos será o primeiro passo básico, mas não menos importante, a ser dado pelo administrador da empresa no processo de formação de preço para a exportação.

Lopez (2007) elenca uma breve lista dos itens relevantes que irão compor o preço: custos de produção, custos de distribuição, custos de promoção, custos variáveis e margem de contribuição. Estes custos são de cunho interno, sendo fundamental o seu domínio para qualquer empresa que planeje atuar, seja no mercado interno ou externo.

Seguindo a linha de pensamento do autor, quando se fala de comércio exterior, entram novos elementos relativos à comercialização internacional, os custos dessa nova estrutura, que na realidade se distribuem pelos demais componentes citados. 
Vários detalhes pesam na composição dos custos externos, dentre os mais comuns: as características, peculiaridades e segmentação de mercado, o poder aquisitivo, o nível de concorrência, a estrutura tributária, a existência de acordos bilaterais ou multilaterais de comércio e a estrutura logística de escoamento, corroborando para a idéia de engenharia de preços de Minervini (2008).

O conhecimento prévio e minucioso dos benefícios, desvantagens, rotinas, mecanismos de apoio creditícios e financeiros, custos, procedimentos e margens de lucro, são fatores que determinam a viabilidade para ingresso e atuação bem-sucedidos no mercado externo. (LOPEZ, 2007)

Conhecido o mercado e as suas variáveis e peculiaridades, parte-se para a terceira peça fundamental, relativa ao poder de percepção e síntese do negociador da empresa. Ela se dá após levantamento dessas informações, na análise dos dados e estruturação das previsões de preço e expectativas de viabilidade negocial.

Todas as informações disponíveis, em princípio, são importantes, como também é importante ter propósitos claros, previamente definidos, quanto ao interesse no mercado externo. Tais premissas, conforme Castro (2007), tendem a facilitar decisões que indiquem caminhos práticos e seguros, permitindo viabilizar os objetivos da empresa. Esse é o papel do negociador, transformar os dados e informações em conhecimentos estratégicos para a empresa e para a melhor tomada de decisão do administrador.

\section{TIPOS DE PREÇO E OS INCOTERMS}

Lopez (2007) prevê quatro tipos de preço a serem trabalhados previstos pela Câmara de Comércio Internacional, os incoterms Ex Work (EXW), Free On board (FOB), Cost, Insurance and Freight (CIF) e DDP. Eles são organizados de acordo com o processo evolutivo de deslocamento da mercadoria do local de origem ao local de destino.

Deduz-se, então, que todos esses fatores devem ser computados nos estudos de preço, visto que a formação de preços transpassa uma simples conta matemática e se posiciona num conjunto mais abarcante.

Os incoterms, ou termos internacionais de comércio, são conceitos universais de responsabilidade de transporte estabelecidos pela câmara de comércio internacional para a uniformização das regras de comércio e a internacional interpretação quanto às responsabilidades de exportadores e importadores.

Utilizando os incoterms tem-se a certeza das responsabilidades de cada parte nas transações comerciais, em relação aos exportadores e importadores, visto que não produz efeitos para as outras partes indiretamente relacionadas como despachantes aduaneiros, operadores portuários, agentes de exportação e outros.

Os incoterms, quando agregados aos contratos de compra e venda, possuem força de lei, auxiliando na interpretação e solução de possíveis mal entendidos ou desavenças judiciais. É importante destacar que a aplicação dos termos internacionais de comércio não é obrigatória nos negócios internacionais e serve como um facilitador nas relações exportador-importador. 
A utilização dos incoterms é feita por meio de 13 siglas denominadas condições de venda, divididas em 4 categorias. Todas essas definições estão dispostas no documento oficial do CCI - Câmara Internacional de Comércio (ICC, 2000). Segue breve explicação abaixo:

Utiliza-se a Categoria E, quando a entrega é feita no estabelecimento do vendedor/exportador. Essa categoria conta com uma condição de venda Ex Work (EXW).

Usa-se Categoria $\mathrm{F}$, quando o transporte principal não é pago pelo exportador. Esse grupo possui 3 condições de venda: Free Carrier (FCA);Free Alongside Ship (FAS); Free On board (FOB).

Aplica-se Categoria $\mathrm{C}$, quando o transporte principal é pago pelo exportador. Esse conjunto conta com 4 condições de venda: Cost and Freight (CFR); Cost, Insurance and Freight (CIF); Carriage Paid To (CPT); Carriage and Insurance Paid To (CIP).

Emprega-se Categoria D, quando a mercadoria é entregue no local de destino. Possui 5 condições de venda: Delivered At Frontier (DAF); Delivered ex-Ship (DES); Delivered exQuay (DEQ); Delivered Duty Unpaid (DDU); Delivered Duty Paid (DDP).

A classificação acima obedece a uma ordem crescente nas obrigações do vendedor, ou seja, se no EXW, o vendedor tem apenas a obrigação de entregar a mercadoria no seu estabelecimento, no local designado; no DDP o vendedor deverá tornar a mercadoria disponível no país do importador no local combinado desembaraçada para importação, assumindo os riscos e custos referentes a impostos e outros encargos até a entrega da mercadoria.

Os incoterms entram definitivamente como um fator essencial para a adequada formação do preço para o mercado internacional. Um bom domínio dos incoterms é indispensável para que o negociador possa incluir todos os seus gastos nas transações em comércio exterior.

Seguindo a recomendação de Lopez (2007), na relação entre formação de preço e incoterms utiliza-se basicamente os incoterms EXW, FOB, CIF, DDP, cada um pertencente a uma categoria. Crê-se que devido a limitações de modalidades de transporte (apenas transporte marítimo) impostas pelos incoterms FOB e CIF, faz-se necessário abranger a definição dos incoterms FCA e CIP. Dessa maneira, destaca-se cada um desses incoterms abaixo.

No incoterm Ex Works (EXW), a mercadoria será colocada a disposição no local designado. Pode ser utilizada em qualquer modalidade de transporte uma vez que logicamente será irrelevante para este termo. Nesta modalidade o comprador arca com todos os gastos de transporte por sua própria conta e risco. Até mesmo o desembaraço e demais formalidades alfandegárias ocorrem por conta e risco do comprador/importador.

Vale ressaltar que por força da legislação no Brasil, é estabelecida como regra geral a responsabilidade do exportador no despacho da mercadoria. Dessa forma, a responsabilidade pela emissão do RE recairá sobre o produtor, salvo em venda a Trading Company ou Empresa Comercial Exportadora. 
Nesse caso será também de sua responsabilidade a obtenção de eventuais certificados oficiais exigidos na operação e também a preparação da embalagem definitiva de exportação. Dessa maneira, para a utilização desse incoterm, as partes devem adequar o termo internacional à legislação brasileira, o que consequentemente vai onerar mais o exportador que ficará responsável por tais obrigações.

Utilizando-se do FOB, a responsabilidade do exportador só será cessada quando a mercadoria estiver já por completa embarcada no navio que fará o transporte no porto de embarque.O FOB tem como modalidade de transporte exclusivamente o transporte marítimo A utilização da cláusula FCA será empregada, no caso de utilizar o transporte rodoviário, ferroviário ou aéreo.

Dessa maneira, ao utilizar o FCA, a obrigação do vendedor termina ao entregar a mercadoria, desembaraçada para a exportação, à custódia do transportador nomeado pelo comprador, no local designado; o desembaraço aduaneiro é encargo do vendedor.

Quando se emprega o CIF o exportador ficará responsável pelo custo de transporte, e a sua cláusula de seguro. A responsabilidade do exportador termina exatamente com a transposição da mercadoria da murada do navio ao descarregar no porto de destino. $\mathrm{O}$ seguro a que este é obrigado a pagar é o seguro mínimo. Esse contrato de seguro de cobertura mínima deverá ser com companhia de boa reputação, de acordo com as instruções da Câmara de Comércio Internacional. Esta modalidade somente pode ser utilizada para transporte marítimo.

Deverá ser utilizado o termo CIP para os casos de transporte rodoviário, ferroviário ou aéreo. Nesse incoterm o frete é pago pelo vendedor até o destino convencionado; os riscos e danos passam para a responsabilidade do comprador no momento em que o transportador assume a custódia das mercadorias.

Por fim, se a opção da negociação for utilizar o incoterm DDP o exportador terá o maior nível de responsabilidade. A mercadoria deve ser entregue já desembaraçada no local designado pelo importador. Pode ser utilizada por qualquer modalidade de transporte.

Vale ressaltar de que, de acordo com Keedi (2001), o incoterm é negociado entre as partes de acordo com o poder de barganha delas, de modo a definir-se as suas responsabilidades em concordância com as melhores condições negociais do vendedor e do comprador.

\section{NOÇÕES GERAIS DO DIREITO TRIBUTÁRIO}

Segundo Werneck (2007), desde a formação dos Estados, datando da Antiguidade, fez-se necessário a tributação como forma de arrecadar recursos para a manutenção do aparato estatal. Há de se ter meios de alimentar os cofres públicos para que ele possa cumprir as suas funções institucionais e sociais.

Dessa necessidade do ente público em obter caixa para a sua manutenção nasce, conseqüentemente, a tributação, que é uma imposição do Estado ao administrado que, em determinadas situações previamente definidas em lei, retira recursos dos mesmos para alimentar o erário. 
Assim, defini-se o tributo, baseado no artigo $3^{\circ}$ do Código Tributário Nacional (CTN), como toda prestação pecuniária compulsória, em moeda ou cujo valor nela se possa exprimir, que não constitua sanção de ato ilícito, instituída em lei e cobrada mediante atividade administrativa plenamente vinculada.

Machado (2004) analisa tal definição e destaca algumas características importantes das particularidades do tributo como: caráter pecuniário, compulsório (o dever de pagar o tributo independente da vontade), sua não constituição em sanção de ato ilícito (natureza diversa da pena), sua instituição em lei (via de regra, somente a lei em sentido estrito pode instituir tributo) e sua cobrança mediante atividade administrativa plenamente vinculada (atividade administrativa de cobrar o tributo é vinculada à lei, não deve a Administração se pautar em outros parâmetros que não os previstos na legislação tributária).

Dessa forma, podemos definir o direito tributário como um ramo do Direito que se ocupa das relações entre o Fisco e as pessoas sujeitas a imposições tributárias de qualquer espécie, limitando o poder de tributar e protegendo os cidadãos contra os abusos desse poder. (MACHADO, 2004)

\section{PRINCÍPIOS CONSTITUCIONAIS NORTEADORES DO SISTEMA TRIBUTÁRIO NACIONAL}

A atividade de tributar, diante de todas as suas peculiaridades, deve-se pautar em alguns princípios. Esses princípios previstos na Norma Ápice são garantias constitucionais para os administrados em relação ao poder de exação da Administração e estão dispostos no Título VI da Constituição Federal - Da Tributação e do Orçamento.

O princípio da legalidade estrita previsto no $\mathrm{CF}$, art. 150, I dispõe que nenhum tributo será instituído ou aumentado a não ser por lei em sentido estrito. As exceções a este princípio estão no art. $153, \S 11^{\circ}$, da CF e são: imposto de importação; imposto de exportação; imposto sobre produto industrializado e imposto sobre operação financeira.

Previsto no CF, art. 150, III, "b", o princípio da anterioridade prevê que é vedada a cobrança de tributos no mesmo exercício financeiro em que haja sido publicada a lei que os instituiu ou aumentou. A emenda constitucional n. 42/03 acrescentou a "garantia nonagésimal", que veda a cobrança de tributos antes de decorridos 90 dias da data em que haja sido publicada a lei que os instituiu ou aumentou.

Existem exceções à anterioridade dispostas nos art. 150, $\S 1 .^{\circ}$, da CF e art. 148, I, da $\mathrm{CF} / 88$, como os: empréstimos compulsórios; impostos sobre importação e exportação; imposto sobre produtos industrializados; impostos extraordinários criados na eminência ou no caso de guerra externa; e impostos sobre operações de crédito, câmbio e seguro, ou relativas a títulos ou valores imobiliários.

O princípio da igualdade (tratar igualmente os iguais, e desigualmente os desiguais, na medida de sua desigualdade) é o princípio da isonomia que consiste na proporcionalidade da incidência à capacidade contributiva, dentre outros aspectos. O princípio da capacidade contributiva, previstos no art. $145, \S 1^{\circ}$ da CF dispõe que os tributos serão graduados, sempre que possível, segundo a capacidade econômica do contribuinte. 
O princípio da competência prevê que a entidade tributante restringe a sua atividade tributária à matéria que lhe foi constitucionalmente destinada. Já o princípio da vedação do confisco veda aos entes tributantes utilizar tributo com efeito de confisco.

Por fim, o princípio da liberdade de tráfego, contido no $\mathrm{CF}, 150$, V veda o estabelecimento de limitações ao tráfego de pessoas ou bens, por meio de tributos interestaduais ou intermunicipais.

\section{ESPÉCIES TRIBUTÁRIAS}

Necessário se faz destacar as diversas espécies de tributos, quais sejam: impostos, taxas, contribuição de melhoria, contribuições sociais e empréstimos compulsórios.

Os impostos são definidos no art. 16 do CTN, como tributo cuja obrigação tem por fato gerador uma situação independente de qualquer atividade estatal específica, relativa ao contribuinte. Assim, afere-se que é um tributo não vinculado à atividade estatal específica.

Já as taxas, previstas no art. 77 do CTN, são definidas como tributos comuns, tendo como fato gerador o exercício regular do poder de polícia, ou a utilização, efetiva ou potencial, de serviço público específico e divisível, prestado ao contribuinte ou posto à sua disposição. Nota-se, já na análise do conceito, a sua vinculação ao poder de polícia ou à utilização, ainda que em potencial, de serviço público específico.

A contribuição de melhoria tem como fato gerador a valorização de imóveis decorrente de obra pública, por força do art. 45, III da Constituição Federal de 1988. Já as contribuições sociais, de acordo com Chimenti (2006), são instituídas pela União para intervenção no domínio econômico, contribuições de interesse de categorias profissionais ou econômicas, e as contribuições de seguridade social.

E, finalmente, os empréstimos compulsórios são instituídos por lei complementar para atender a despesas extraordinárias, decorrentes de calamidade pública, de guerra externa ou sua iminência e no caso de investimento de caráter urgente e de relevante interesse nacional, de acordo com o art. 148 da Constituição Federal.

\section{CLASSIFICAÇÃO DOS TRIBUTOS}

Além da classificação quanto à espécie, tem o tributo outras classificações como quanto à competência, quanto à vinculação e quanto à função, de acordo com Machado (2004). Quanto à competência os tributos são: federais, estaduais e municipais. Em se tratando de imposto, é possível produzir uma listagem da competência de cada imposto estabelecido baseado no art. $147 \mathrm{da}$ CC, a seguir.

Os impostos federais, dispostos no art. 153 da CF são os seguintes: Imposto sobre Importação (II); Imposto sobre a Exportação (IE); Imposto sobre a Renda e Proventos (IR); Imposto de Produtos Industrializados (IPI); Imposto sobre Operações Financeiras (IOF); Imposto sobre a Propriedade Territorial Rural (ITR); e Imposto sobre Grandes Fortunas (IGF). 
Os impostos estaduais e do Distrito Federal estão previstos no art. 155 da CF: Imposto sobre Transmissão Causa Mortis e Doações (ITCMD); Imposto sobre Operações de Circulação de Mercadoria e de Prestação de Serviços de Comunicação e Transporte Interestadual e Intermunicipal (ICMS); e Imposto sobre Propriedade de Veículos Automotores (IPVA).

Já os impostos municipais e do Distrito Federal, por força dos art. 156 são: Imposto sobre a Propriedade Predial e Territorial Urbano (IPTU); Imposto sobre Transmissão Inter Vivos (ITIV); e Imposto sobre Serviços de Qualquer Natureza (ISSQN).

Quanto à vinculação com a atividade estatal Hugo de Brito Machado (2004) classifica os tributos como: vinculados (taxas, contribuições de melhoria e contribuições sociais) e não vinculados (impostos).

Quanto à função, a literatura tributária, em concordância com Hugo de Brito Machado (2004) e Chimenti (2006), classifica os tributos como: fiscais (quando o tributo visa, principalmente, a arrecadação de recursos para o Estado), extrafiscais (quando tem por objetivo principal função diversa da arrecadação de recursos para os cofres públicos) e parafiscais (tem por objetivo custear atividades diversas das funções próprias do Estado, mas este as desenvolve através de entidades específicas).

\section{DISTINÇÃO ENTRE NÃO INCIDÊNCIA, IMUNIDADE, ISENÇÃO E ALÍQUOTA ZERO}

Como nos ensina Bonfim (2004), é de bom senso explicar antecipadamente as diferenças existentes entre não incidência, imunidade, isenção, e a "alíquota zero".

A não-incidência se dá quando não ocorre nenhum fato ou quando ocorre um fato tributariamente irrelevante (fato não imponível). Por vezes, porém, fatos tributariamente irrelevantes podem tornar-se tributariamente relevantes, de acordo com o contexto que está inserido, bastando que o ente político o defina como fato imponível.

No tocante às imunidades, as mesmas são normas constitucionais de estrutura que objetivam auxiliar no delineamento do campo de competência das entidades tributantes. Atuam impedindo que a atividade legislativa impositiva legifere em matéria tributária, sobre determinados fatos, bens, pessoas ou situações protegidos pela constituição. (BONFIM, 2004)

O autor afirma que a imunidade pode ser estabelecida em relação a determinado sujeito (como as pessoas políticas), ou pode ser fixada em função de um bem (como as imunidade dos livros). Dessa forma, é claro que, nestes casos, o instrumento normativo que institui o tributo não poderá alcançar as hipóteses de imunidade.

Quanto às isenção, continua o autor, tratam-se das normas de estrutura (preceitos jurídicos que visam modificar regras existentes no sistema) que objetivam provocar modificações na regra-matriz de incidência, investindo contra um ou mais de seus critérios de forma a retirar sua eficácia técnica, impedindo que o fato nela descrito tenha o condão de, assim que ocorrido, gerar os efeitos previstos. 
Dessa forma, de acordo com Bonfim (2010), pressupõe um encontro normativo entre a regra de isenção e a regra-matriz de incidência tributária, operando como redutor do campo de abrangência dos critérios constantes da hipótese ou da consequiência. $\mathrm{O}$ efeito prático é impedir o nascimento da obrigação tributária, por meio de normas infraconstitucionais.

No caso da alíquota zero, esta também uma fórmula de suspensão de um dos critérios da regra matriz de incidência tributária, qual seja, o da alíquota (critério quantitativo). Nela, não há o nascimento da relação jurídica tributária, posto que não é possível estabelecer no conseqüente, qualquer que seja a base de cálculo utilizada, o objeto jurídico da relação tributária.

Por fim, a imunidade, isenção ou alíquota zero, tem como efeito prático comum a inexistência da obrigação tributária de forma a que muito embora o sujeito pratique determinado fato, ou ocorra determinado evento, inexistirá o nascimento da obrigação tributária.

\section{EXAÇÃO NAS OPERAÇÕES DE COMÉRCIO EXTERIOR}

O pujante crescimento do fluxo de comércio exterior brasileiro é uma realidade inconteste. A taxa de crescimento constante pode ser vista claramente no gráfico 1 e na tabela 1 (BRASIL, 2009a), principalmente do salto dado a partir no ano de 2003, quando as exportações saíram do patamar de 73 milhões de dólares FOB, e almejaram os 96 milhões US\$ FOB, em 2004 e ultrapassaram os 1 bilhões US\$ FOB, a partir de 2005.

Na Tabela 1 (BRASIL, 2009a), analisa-se que nos últimos cinco anos (2004-2008), as exportações cresceram à taxa média anual de $22,2 \%$, número que contrasta com o referente aos 25 anos anteriores, quando as exportações cresceram apenas a taxas de 6,7\% ao ano, de acordo com dados do MDIC/SECEX. (BRASIL 2008a).

Tal desempenho permitiu que o País registrasse também uma forte expansão das importações $24,9 \%$ ao ano no período 2004-2008 e ainda assim alcançasse recordes em seus superávits comerciais, que atingiram valores superiores a US\$46 milhões no triênio 2006-2008.

Tabela 1: Saldo Comercial Brasileiro

\begin{tabular}{l|r|r|r|r|r}
\hline Ano & $\begin{array}{c}\text { Exportação Total } \\
\text { (US\$ milhões } \\
\text { FOB) }\end{array}$ & Variação (\%) & $\begin{array}{c}\text { Importação Total } \\
\text { (US\$ milhões FOB) }\end{array}$ & Variação (\%) & $\begin{array}{c}\text { Saldo Comercial } \\
\text { (US\$ milhões } \\
\text { FOB) }\end{array}$ \\
\hline 2001 & & & & \\
2002 & 58.223 & 5,7 & 55.602 & $(249)$ & 2.621 \\
2003 & 60.362 & 3,7 & 47.243 & $(8.359)$ & 13.119 \\
2004 & 73.084 & 21,1 & 48.326 & 1.083 & 24.758 \\
2005 & 96.475 & 32 & 62.836 & 14.510 & 33.639 \\
2006 & 118.308 & 22,6 & 73.600 & 10.765 & 44.708 \\
2007 & 137.807 & 16,5 & 91.349 & 17.749 & 46.458 \\
2008 & 160.649 & 16,6 & 120.621 & 29.272 & 40.028 \\
\hline
\end{tabular}

Fonte: Adaptado de BRASIL (2009a) 


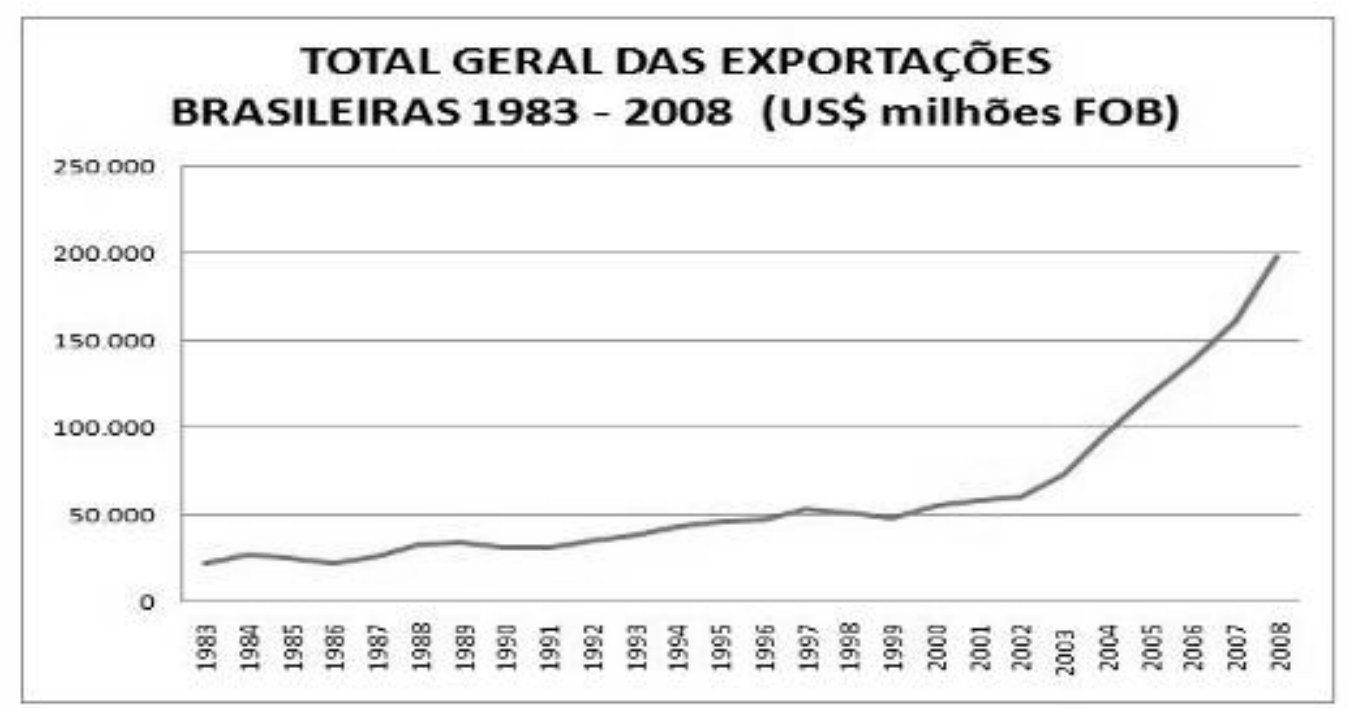

\section{Gráfico 1: Exportações Brasileiras.}

Fonte: adaptado BRASIL (2009a)

Na tabela 2 podemos analisar o aumento da evolução do PIB brasileiro nos últimos anos (2001-2008). O excelente desempenho exportador permitiu que a participação das exportações no PIB aumentasse substancialmente. Esta participação que de uma média de 6\% na participação desde a década de 80, situou-se acima de 12\% em 2007 (BRASIL, 2008a). Dessa maneira, vislumbra-se que o desempenho exportador colabora para a evolução do PIB nos últimos anos. O Brasil, segundo os dados da CIA - Central Intelligence Agency, em 2008 ocupou a $10^{\mathrm{a}}$ maior economia mundial. (CIA, 2009)

\section{Tabela 2: Evolução do PIB brasileiro}

\begin{tabular}{lcccc}
\hline Ano & $\mathbf{E m}$ milhões de reais & $\begin{array}{c}\text { Pet capita, em reais } \\
\text { correntes }\end{array}$ & $\begin{array}{c}\text { Taxa de variação real } \\
\text { no ano }\end{array}$ \\
\hline $\mathbf{2 0 0 1}$ & $1.198 .736,19$ & $6.896,35$ & $1,3 \%$ \\
$\mathbf{2 0 0 2}$ & $1.346 .027,55$ & $7.630,93$ & $2,7 \%$ \\
$\mathbf{2 0 0 3}$ & $1.556 .182,11$ & $8.694,47$ & $1,1 \%$ \\
$\mathbf{2 0 0 4}$ & $1.766 .621,03$ & $9.728,84$ & $5,7 \%$ \\
$\mathbf{2 0 0 5}$ & $1.937 .598,29$ & $10.519,88$ & $3,2 \%$ \\
$\mathbf{2 0 0 6}$ & $2.300 .133,20$ & $12.688,04$ & $4,0 \%$ \\
$\mathbf{2 0 0 7}$ & $2.558 .000,00$ & $13.515,00$ & $5.7 \%$ \\
$\mathbf{2 0 0 8}$ & $2.889 .719,00$ & $15.240,00$ & $5,1 \%$ \\
\hline
\end{tabular}

Fonte:BACEN (2009)

Como podemos ver no gráfico 2, o País também logrou êxito ao aumentar sua participação nas exportações mundiais nos últimos anos, alcançando $1,17 \%$ em 2007, tendo partido de apenas $0,85 \%$ em 1999-2000. Embora possa parecer pouco, esse aumento de 0,22 pontos percentual representa, em valores atuais, um acréscimo de cerca de US\$ 44 bilhões. Sabese que o Brasil tem um grande potencial para o crescimento de suas exportações. 


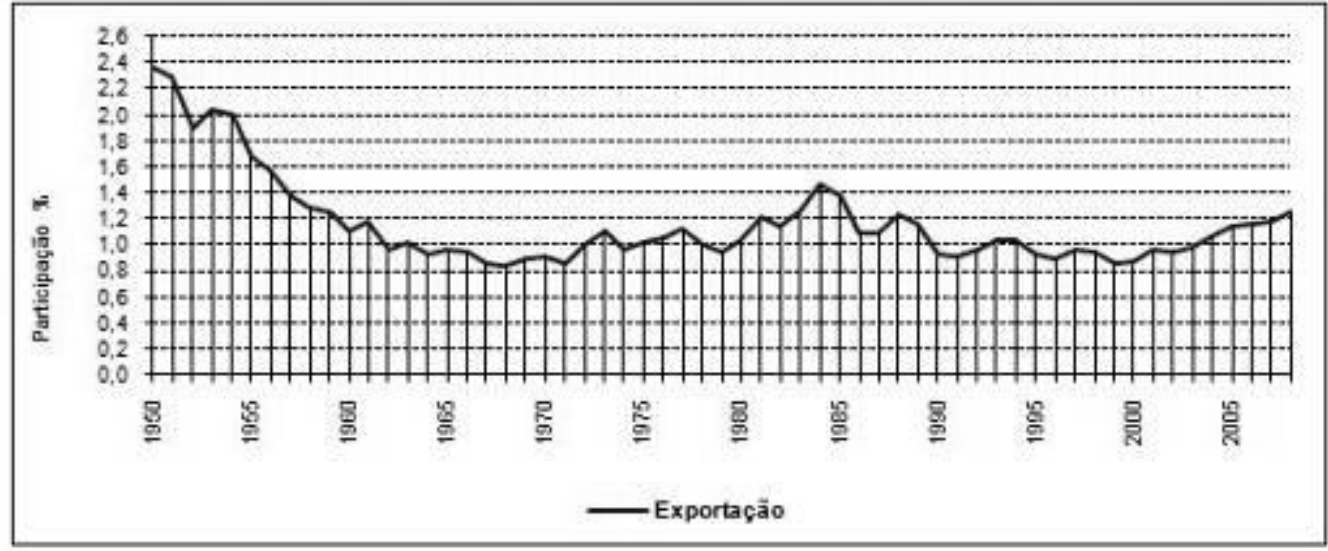

Gráfico 2: Participação brasileira nas exportações mundiais. Fonte: BRASIL (2009a)

De acordo com Lopez (2007), para que o saldo comercial permaneça em patamar bastante positivo é necessário a promoção de um crescimento forte e sustentável das exportações. Não é um desafio simples, tendo em vista as dificuldades históricas que o Brasil tem enfrentado para sustentar um crescimento relativamente elevado das exportações durante um longo período de tempo. A promoção de um comércio exterior forte e sustentável torna o país menos vulnerável a variações externas.

O perfil e a magnitude deste desafio devem ser adequadamente avaliados para que se possam identificar claramente quais são os principais problemas e para que se possa definir uma estratégia para superá-los.

A avaliação dos desafios perpassa por duas análises: uma análise da estrutura atual da pauta exportadora brasileira e de sua evolução ao longo do tempo, em termos de produtos, mercados de destino e perfil das empresas exportadoras; e uma avaliação dos fatores de ordem estrutural que afetam mais diretamente a competitividade da produção nacional e que, portanto, condicionam a expansão das vendas externas do País.

Construindo a primeira análise, com relação à composição da pauta exportadora segundo setores e/ou produtos, análises baseadas em diferentes classificações mostram que não houve mudanças drásticas na composição ao longo dos últimos anos, embora tenham surgido algumas novidades importantes.

Considerando-se a classificação segundo classes de produtos, por exemplo, os manufaturados são o grupo de maior peso na pauta, e tem sido assim desde o início da década de 1980, com sua participação mantendo-se entre $50 \%$ a $55 \%$ do total, de acordo com o relatório do MDIC/SECEX (BRASIL, 2008a). 
Tabela 3: Produtos mais exportados: exportações segundo as principais mercadorias Janeiro a Setembro de 2009

\begin{tabular}{c|c|c|c}
\hline DESCRIÇÃO & VALOR & PART. \% & ACUM. \% \\
\hline Soja mesmo triturada & 10.926 .103 & 9,78 & 9,78 \\
Minérios de ferro e seus concentrados & 10.034 .643 & 8,98 & 18,76 \\
Petróleo & 6.192 .806 & 5,54 & 24,31 \\
Açúcar & 5.569 .623 & 4,99 & 29,3 \\
Farelo de soja & 3.660 .090 & 3,28 & 32,57 \\
Carnes de aves & 3.611 .217 & 3,23 & 35,81 \\
Aeronaves & 2.893 .531 & 2,59 & 38,4 \\
Fumo & 2.715 .753 & 2,43 & 40,83 \\
Café mesmo torrado ou descafeinado & 2.325 .959 & 2,08 & 42,91 \\
Automóveis de passageiros e outros & 2.217 .301 & 1,99 & 44,89 \\
veículos & 2.174 .495 & 1,95 & 46,84 \\
Celulose & 2.059 .854 & 1,84 & 48,69 \\
Óleos de petróleo ou de minerais & 1.913 .834 & 1,71 & 50,4 \\
betuminosos & 1.700 .255 & 1,52 & 51,92 \\
Carnes bovinas congeladas & & & 53,06 \\
Partes e acessórios dos veículos & 1.274 .278 & 1,14 & \\
automóveis & & & 54,16 \\
Sucos de frutas incluídos os mostos de & 1.231 .512 & 1,1 & \\
uvas & & &
\end{tabular}

\section{Fonte: BRASIL, 2009b}

A classificação segundo setores produtivos, contido na tabela 3, mostra que continua havendo uma expressiva concentração em atividades mais tradicionais, como metalurgia básica, agricultura e pecuária e extração de minerais metálicos, mas não se pode ignorar o crescimento expressivo das vendas de veículos automotores, máquinas e equipamentos e aviões, além de petróleo e derivados.

Outro ponto importante refere-se à distribuição das exportações brasileiras segundo países e regiões de destino. O esforço do governo para a diversificação dos destinos das vendas brasileiras somou-se ao interesse e à disposição crescentes do setor privado em buscar novos mercados compradores.

De acordo com Lopez (2007), o desempenho brasileiro a esse respeito tem se mostrado bastante favorável, observando-se que os mercados mais tradicionais vêm perdendo participação em benefício de mercados não-tradicionais.

Para corroborar com tal ideia, podemos ver, por meio da tabela 4 que em relação à variação do valor nos anos de 2009-2008 das exportações por países, que os mercados tradicionais estão com menores participações como destinos das exportações brasileiras, à exemplo da União Européia (Variação negativa do valor de 27\%) Estados Unidos (Variação Negativa de $15 \%$ ). Novos mercados surgem na dinâmica das exportações como China, África, Oriente Médio, Europa Oriental e mesmo os países da América Central.

Tabela 4- Principais mercados de destino das exportações - 2009-2008 - US\$ Milhões 


\begin{tabular}{|c|c|c|c|c|c|}
\hline PRINCIPAIS MERCADOS & $2009-$ & Part & 2008 - & Part & Variacão \% \\
\hline ESTADOS UNIDOS & 129.399.722 & 15,70 & 152.571 .144 & 16,30 & $-15,19$ \\
\hline VENEZUELA & 88.717 .933 & 10,77 & 42.546 .750 & 4,55 & 108,52 \\
\hline ARGENTINA & 76.048 .115 & 9,23 & 106.197.317 & 11,35 & $-28,39$ \\
\hline PAISES BAIXOS (HOLANDA) & 60.524 .120 & 7,35 & 85.447 .784 & 9,13 & $-29,17$ \\
\hline RUSSIA, FEDERACAO DA & 53.273 .107 & 6,47 & 34.700 .387 & 3,71 & 53,52 \\
\hline PROVISAO DE NAVIOS E & 32.685 .704 & 3,97 & 51.067 .578 & 5,46 & $-36,00$ \\
\hline URUGUAI & 29.137.852 & 3,54 & 25.580 .806 & 2,73 & 13,91 \\
\hline REINO UNIDO & 27.899 .690 & 3,39 & 35.532 .977 & 3,80 & $-21,48$ \\
\hline LIBIA & 26.000 .523 & 3,16 & 22.689 .697 & 2,42 & 14,59 \\
\hline CHILE & 20.391 .423 & 2,47 & 25.438 .428 & 2,72 & $-19,84$ \\
\hline PORTUGAL & 16.503 .935 & 2,00 & 15.187.371 & 1,62 & 8,67 \\
\hline \multicolumn{6}{|c|}{ PRINCIPAIS BLOCOS ECONÔMICOS } \\
\hline UNIAO EUROPEIA - UE & 140.309 .583 & 17,03 & 194.590 .019 & 20,80 & $-27,89$ \\
\hline $\begin{array}{c}\text { AFRICA (EXCLUSIVE ORIENTE } \\
\text { MEDIO) }\end{array}$ & 138.407 .021 & 16,80 & 141.739 .467 & 15,15 & $-2,35$ \\
\hline $\begin{array}{l}\text { ESTADOS UNIDOS (INCLUSIVE } \\
\text { PORTO RICO) }\end{array}$ & 135.892 .835 & 16,49 & 153.781 .622 & 16,43 & $-11,63$ \\
\hline ALADI (EXCLUSIVE MERCOSUL) & 133.068 .921 & 16,15 & 89.553 .463 & 9,57 & 48,59 \\
\hline $\begin{array}{l}\text { MERCADO COMUM DO SUL - } \\
\text { MERCOSUL }\end{array}$ & 112.083 .237 & 13,60 & 139.163 .810 & 14,87 & $-19,46$ \\
\hline DEMAIS BLOCOS & 164.210 .299 & 19,93 & 216.913.997 & 23,18 & $-24,30$ \\
\hline
\end{tabular}

Fonte: BRASIL (2009a)

Ressalta-se que quanto mais variados os mercados destinos, menor a dependência do Brasil em relação aos mercados e consequentemente menores os riscos da atuação brasileira no comércio exterior. O Brasil tem grandes possibilidades de diversificar ainda mais suas vendas, especialmente se reforçar suas iniciativas de promoção comercial nesses novos mercados e se evoluir na negociação de acordos comerciais que melhorem as condições de acesso dos produtos brasileiros aos diversos mercados.

A análise do aspecto estrutural na busca de um comércio exterior sustentável, de acordo com Lopez (2007), relaciona-se à capacitação tecnológica das empresas e à qualificação de mão-de-obra. Com efeito, de acordo com o autor, o ritmo de inovação na indústria brasileira tem sido pouco expressivo como podemos ver na tabela 5, abaixo.

Tabela 5: Exportação brasileira dos setores industriais por intensidade tecnológica 
FREITAS \& MEIRELES (2010)

\begin{tabular}{|c|c|c|c|c|c|c|c|c|}
\hline \multirow{4}{*}{ Setores } & \multicolumn{6}{|c|}{ 2009/2008 - US\$ milhões FOB } & & \\
\hline & \multirow[b]{3}{*}{ Valor } & \multicolumn{2}{|c|}{2009} & \multicolumn{3}{|c|}{2008} & \multirow{2}{*}{\multicolumn{2}{|c|}{ Var. 2009/08 }} \\
\hline & & $\mathrm{Pa}$ & & & \multicolumn{2}{|c|}{ Part. \% } & & \\
\hline & & Total & $\begin{array}{c}\text { Produtos } \\
\text { Industriais }\end{array}$ & Valor & Total & $\begin{array}{c}\text { Produtos } \\
\text { Industriais }\end{array}$ & Abs. & Rel. \% \\
\hline Total & 152.995 & 100,0 & - & 197.942 & 100,0 & - & -44.948 & $-22,7$ \\
\hline Produtos industriais ( ${ }^{*}$ ) & 104.608 & 68,4 & 100,0 & 141.890 & 71,7 & 100,0 & -37.282 & $-26,3$ \\
\hline Industria de alta e média-alta tecnologia (I+II) & 36.254 & 23,7 & 34,7 & 51.630 & 26,1 & 36,4 & -15.376 & $-29,8$ \\
\hline Indústria de alta tecnologia (I) & 9.048 & 5,9 & 8,6 & 11.507 & 5,8 & 8,1 & -2.459 & $-21,4$ \\
\hline Aeronáutica e aeroespacial & 4.536 & 3,0 & 4,3 & 6.064 & 3,1 & 4,3 & -1.528 & $-25,2$ \\
\hline Farmacêutica & 1.550 & 1,0 & 1,5 & 1.482 & 0,7 & 1,0 & 68 & 4,6 \\
\hline Material de escritório e informática & 203 & 0,1 & 0,2 & 235 & 0,1 & 0,2 & -32 & $-13,7$ \\
\hline Equipamentos de rádio, TV e comunicação & 2.045 & 1,3 & 2,0 & 2.871 & 1,5 & 2,0 & -826 & $-28,8$ \\
\hline Instrumentos médicos de ótica e precisẫo & 714 & 0,5 & 0,7 & 854 & 0,4 & 0,6 & -140 & $-16,4$ \\
\hline Indústria de média-alta tecnologia (II) & 27.206 & 17,8 & 26,0 & 40.123 & 20,3 & 28,3 & -12.918 & $-32,2$ \\
\hline Máquinas e equipamentos elétricos $n . e$. & 2.997 & 2,0 & 2,9 & 3.777 & 1,9 & 2,7 & -780 & $-20,6$ \\
\hline Veiculos automotores, reboques e semi-reboques & 9.351 & 6,1 & 8,9 & 16.293 & 8,2 & 11,5 & -6.943 & $-42,6$ \\
\hline Produtos químicos, excl. farmacêuticos & 7.536 & 4,9 & 7,2 & 8.772 & 4,4 & 6,2 & -1.236 & $-14,1$ \\
\hline Equipamentos para ferrovia e material de transporte n. e. & 346 & 0,2 & 0,3 & 496 & 0,3 & 0,3 & -150 & $-30,2$ \\
\hline Máquinas e equipamentos mecânicos n. e. & 6.976 & 4,6 & 6,7 & 10.785 & 5,4 & 7,6 & -3.810 & $-35,3$ \\
\hline Indústria de média-baixa tecnologia (III) & 24.715 & 16,2 & 23,6 & 38.870 & 19,6 & 27,4 & -14.155 & $-36,4$ \\
\hline Construção e reparaçăo naval & 119 & 0,1 & 0,1 & 1.541 & 0,8 & 1,1 & -1.422 & $-92,3$ \\
\hline Borracha e produtos plásticos & 2.320 & 1,5 & 2,2 & 2.870 & 1,4 & 2,0 & -550 & $-19,2$ \\
\hline Produtos de petróleo refinado e outros combustiveis & 5.791 & 3,8 & 5,5 & 9.489 & 4,8 & 6,7 & -3.697 & $-39,0$ \\
\hline Outros produtos minerais não-metálicos & 1.522 & 1,0 & 1,5 & 2.080 & 1,1 & 1,5 & -559 & $-26,8$ \\
\hline Produtos metálicos & 14.963 & 9,8 & 14,3 & 22.891 & 11,6 & 16,1 & -7.927 & $-34,6$ \\
\hline Indústria de baixa tecnologia (IV) & 43.639 & 28,5 & 41,7 & 51.389 & 26,0 & 36,2 & -7.750 & $-15,1$ \\
\hline Produtos manufaturados n.e. e bens reciclados & 1.326 & 0,9 & 1,3 & 1.759 & 0,9 & 1,2 & -432 & $-24,6$ \\
\hline Madeira e seus produtos, papel e celulose & 6.722 & 4,4 & 6,4 & 8.651 & 4,4 & 6,1 & -1.929 & $-22,3$ \\
\hline Alimentos, bebidas e tabaco & 31.737 & 20,7 & 30,3 & 35.373 & 17,9 & 24,9 & -3.636 & $-10,3$ \\
\hline Têxteis, couro e calçados & 3.854 & 2,5 & 3,7 & 5.607 & 2,8 & 4,0 & -1.753 & $-31,3$ \\
\hline Produtos não industriais & 48.387 & 31,6 & - & 56.053 & 28,3 & - & -7.666 & $-13,7$ \\
\hline
\end{tabular}

Fonte: BRASIL (2009a)

Como podemos analisar no quadro 1, o nível de intensidade tecnológica das exportações brasileiras é baixo, concentrando, 31,6\% das exportações sem industrialização, e 28,5\% da indústria de baixa tecnologia, resultando num total de $60,1 \%$ dos produtos exportados pelo Brasil de baixa ou nenhuma intensidade tecnológica e apenas $23,7 \%$ de produtos de média alta ou alta intensidade tecnológica.

A composição da pauta de exportação do País segundo a intensidade tecnológica dos produtos exportados reflete no baixo nível de inovação das empresas industriais. Ao lado desse problema está a escassez de mão-de-obra qualificada, o que limita a capacidade de as empresas incorporarem avanços tecnológicos em seus processos produtivos.

No contexto da avaliação dos fatores de ordem estrutural que afetam mais diretamente a competitividade da produção nacional, a questão dos acordos comerciais também assume grande importância, tendo em vista o acirramento da concorrência internacional e a multiplicação de acordos bilaterais e regionais, que acabam por erodir a posição competitiva do Brasil em diversos mercados por conta da concessão de preferências comerciais a terceiros países.

Lopez (2007) expõem que embora se possa argumentar que os acordos comerciais não fizeram falta no período recente em que as exportações cresceram significativamente, beneficiadas por uma boa fase no comércio internacional, esse quadro pode ser diferente em um eventual período de retração da economia mundial. 
O mesmo autor cita ainda, por fim, a questão dos procedimentos burocráticos relacionados às operações de comércio exterior. A despeito de todo o esforço de desburocratização já feito para facilitar e agilizar os procedimentos, as empresas ainda enfrentam, especialmente as firmas de menor porte, dificuldades para cumprir todas as exigências em um prazo razoável e sem incorrer em custos significativos.

A análise apresentada evidencia que, a despeito das ações já realizadas nos últimos anos de evolução do comércio internacional brasileiro, ainda há muitos desafios a serem enfrentados para que o País possa aproveitar de forma plena o seu potencial exportador. A superação desses desafios exige uma estratégia estruturada e consistente, com programas, ações e instrumentos que contemplem as diversas questões citadas acima.

Todas essas questões influenciam diretamente o processo de formação de preço do produto para o mercado internacional. São fatores macroeconômicos que afetam a todas as empresas como um todo e por igual. O tratamento fiscal diferenciado na exportação é mais uma estratégia estruturada para a construção de um comércio exterior sustentável e crescente.

\section{SISTEMA TRIBUTÁRIO E O COMÉRCIO EXTERIOR BRASILEIRO}

De acordo com Machado (2004), o Direito Tributário tem como objetivo principal a arrecadação de divisas para os cofres públicos. É mais do que natural que os fatos geradores dos tributos estejam vinculados a situações que envolvam o manuseio de dinheiro ou posses, tais quais os atos de comércio, de uma forma geral, como também os impostos sobre a propriedade.

Nesse contexto, o comércio exterior é um alvo previsível como hipótese de incidência de determinados tributos, visto que enormes divisas circulam através do comércio internacional de mercadorias.

É lógico, seguindo essa linha de pensamento, que essa situação tem que estar de acordo os princípios do Direito Tributário, principalmente com os princípios da isonomia e da proporcionalidade, capacidade contributiva, uma vez que essas operações partem de pessoas que têm posses, refletindo-se estas no próprio volume de operações desenvolvidas por cada pessoa.

Porém, ao mesmo tempo que estão colmatados nos princípios do direito tributário, os impostos: Imposto de Importação, Imposto sobre Produto Industrializado, Imposto de Exportação e Imposto sobre Operações Financeiras (II, IPI, IE e IOF, respectivamente) apresentam particularidades quanto ao princípio da anterioridade e da legalidade, como já exposto.

Essa particularidade é o princípio da excepcionalidade dos impostos incidentes no comércio exterior em relação à anterioridade da lei tributária, presente no art. $150, \S 1^{\circ}$, e também à legalidade, haja vista que podem ser facultativamente outorgados ao poder executivo a alteração de suas alíquotas, atendidas as condições e limites estabelecidos em lei, de acordo com o art.153, §1, de acordo com Freitas (2006). 
Dessa maneira, os princípios da anterioridade e da legalidade são minorados devido o caráter extrafiscal desses impostos. Os impostos incidentes no comércio exterior apresentam como função essencial a extrafiscalidade, que tem como objetivo principal a função diversa da arrecadação, apresentando um caráter regulatório, estimulando, induzindo, coibindo condutas, em se tratando de comércio exterior, regulando-o e protegendo a indústria nacional à luz do ordenamento jurídico positivo. (FREITAS, 2006)

Destarte, sintetiza-se a definição de extraficascalidade, de acordo com Gouvêa (2010):

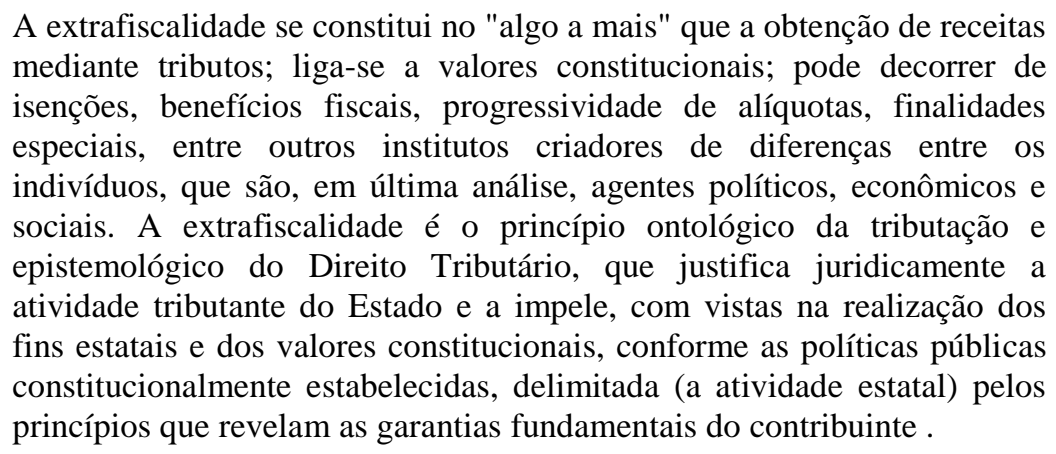

Podemos visualizar exemplos da extrafiscalidade através do Imposto de Exportação, quando a União estimula a exportação reduzindo ou até dispensando a carga tributária para essas operações, ou, procura inibir essas operações através do incremento do ônus tributário. Em alguns casos em que a exportação não é interessante para o país, é cobrado o imposto de exportação para desestimular a saída de tal produto do país.

Há também a regulamentação das importações por meio do II, para que o produto importado chegue às mãos do consumidor. Ele é tributado pelo imposto de importação com finalidade extrafiscal de orientar a economia e atender aspectos de desenvolvimento social, e pelos tributos internos, que cumprem a finalidade fiscal. (WERNECK, 2007)

O Imposto de Importação pode ser estimulado pelo governo através da diminuição de suas alíquotas, como forma de, por exemplo, aumentar a competitividade em determinado segmento e, conseqüentemente, reduzir o preço interno de determinados produtos, ou, ao contrário, onera a importação, o que é mais comum, como forma de proteger a indústria nacional. (CASTRO, 2007)

Werneck (2007) nos ensina que a regra geral do comércio internacional atual é a desoneração total das exportações para a facilitação das movimentações de exportação, aumentando a competitividade e fazendo com que os países gozem dos seus benefícios como geração de empregos e de divisas.

Assim exposto, existem tributos que possuem uma importância especial no comércio exterior como o Imposto sobre Produto Industrializado (IPI), Imposto sobre Operações de Circulação de Mercadoria e de Prestação de Serviços (ICMS), Programa de Integração Social (PIS), Contribuição para o Financiamento da Seguridade Social (COFINS), Imposto sobre Operações Financeiras (IOF), o Imposto de Importação (II) e o Imposto de Exportação (IE). 
Além desses tributos, outros são incidentes no comércio exterior, como a taxa de utilização do sistema integrado de comércio exterior e o adicional ao frete para renovação da Marinha Mercante, que são essenciais para a elaboração de preços no comércio exterior.

\section{TRATAMENTO TRIBUTÁRIO NA EXPORTAÇÃO}

Em um mercado extremamente globalizado, como o atual, o empresário disputa o mercado cada vez mais concorrente num ambiente sujeito às mais diversas flutuações causadas por inúmeras variáveis. Nesse contexto de internacionalização da economia, as empresas, bem como os países que elas representam precisam apresentar diferenciais de competitividade, para se estabelecer no comércio exterior. Os países, por meio de acordo no GATT, costumam incentivar as exportações.

Esse incentivo vai além da não cobrança do imposto de exportação, abrangendo a desoneração de tributos que incidem ao longo da cadeia produtiva, afetando diretamente o custo de fabricação do produto, tais como: IPI, ICMS, IOF, PIS e COFINS.

Por força constitucional (art. 155, X, a, da CF), o ICMS não incide sobre operações de produtos industrializados que se destinem ao exterior. A Norma Maior exclui da não incidência os semi-elaborados, para que sejam definidos em lei complementar, de acordo com o ar. 155. XI, e.

Dessa maneira, a Lei Complementar n ${ }^{\circ}$ 87/96 (conhecida como Lei Kandir), teve impactos positivos na cadeia produtiva, pois desonera a cobrança do ICMS nas exportações de produtos primários e semi-elaborados, a aquisição de bens de capital, a energia consumida e os bens de uso e consumo das empresas.

Dessa maneira, o ICMS é imune, por força de norma constitucional, no que concerne aos produtos industrializados com destinação ao exterior, e isento, por disposição infraconstitucional, em relação aos produtos primários e semi-elaborados.

O ICMS é o único imposto do comércio exterior que tem competência estadual. Dessa forma, seu fato gerador e sua base de cálculo serão instituídos por lei de arrecadação estadual, respeitado as normas gerais dispostas na Lei Complementar $n^{\circ} 87 / 96$ e art. 155 da Constituição Federal. O ICMS é um imposto não-cumulativo, de acordo com o inciso I, $\S 2^{\circ}$, art. 155 da CF.

Por ser de competência estadual, a normalização do ICMS cria uma série de polêmicas quanto à política adotada pelos Estados na sua cobrança. Um desses problemas é a guerra fiscal, quando um Estado oferece vários benefícios, entre eles tributário, para que as indústrias se instalem nos seus territórios, buscando em contrapartida a geração de emprego, trabalho e renda.

As alíquotas instituídas diferentemente de acordo com a normalização de cada Estado podem servir como parâmetro de escolha estratégica para a fixação de uma empresa em determinado Estado Federado. No quadro abaixo, encontram-se as alíquotas de ICMS de cada estado, fornecidos no sítio da FISCONTEX. (FISCONTEX 2010) 
De acordo com o quadro 1, os Estados de Minas Gerais, Paraná, Rio de Janeiro, São Paulo, Santa Catarina e Rio Grande do Sul apresentam alíquotas interestaduais menores que os demais Estados (a alíquota gira em torno de 7\%, enquanto os outros Estados apresentam alíquota interestadual de 12\%). Em contrapartida, as alíquotas internas desses estados costuma ser igual à média nacional (17\%) ou maior, e entre esses estados, a alíquota interestadual acompanha a média nacional $(12 \%)$.

\begin{tabular}{|c|c|c|c|c|c|c|c|c|c|c|c|c|c|c|c|c|c|c|c|c|c|c|c|c|c|c|c|c|}
\hline $\begin{array}{c}\text { Alíquota } \\
\text { Interna } \\
\text { do } \\
\text { ICMS }\end{array}$ & & & & & & & & & & & & & & & & & & & & & & & & & & & & \\
\hline & & $A C$ & & $\mathrm{AM}$ & AP & BA & $\mathrm{CE}$ & DF & ES & GO & MA & & MS & MG & & PB & PR & PE & $\mathrm{PI}$ & RN & & RJ & Ro & RR & $\mathrm{sc}$ & $\mathrm{SP}$ & SE & TO \\
\hline & $A C$ & 17 & 12 & 12 & 12 & 12 & 12 & 12 & 12 & 12 & 12 & 12 & 12 & 12 & 12 & 12 & 12 & 12 & 12 & 12 & 12 & 12 & 12 & 12 & 12 & 12 & 12 & 12 \\
\hline & $\mathrm{AL}$ & 12 & 17 & 12 & 12 & 12 & 12 & 12 & 12 & 12 & 12 & 12 & 12 & 12 & 12 & 12 & 12 & 12 & 12 & 12 & 12 & 12 & 12 & 12 & 12 & 12 & 12 & 12 \\
\hline & AM & 12 & 12 & 17 & 12 & 12 & 12 & 12 & 12 & 12 & 12 & 12 & 12 & 12 & 12 & 12 & 12 & 12 & 12 & 12 & 12 & 12 & 12 & 12 & 12 & 12 & 12 & 12 \\
\hline & AP & 12 & 12 & 12 & 17 & 12 & 12 & 12 & 12 & 12 & 12 & 12 & 12 & \begin{tabular}{|l|}
12 \\
\end{tabular} & 12 & 12 & 12 & 12 & 12 & 12 & 12 & 12 & 12 & 12 & 12 & 12 & 12 & 12 \\
\hline & BA & 12 & 12 & 12 & 12 & 17 & 12 & 12 & 12 & 12 & 12 & 12 & 12 & \begin{tabular}{|l|}
12 \\
\end{tabular} & 12 & 12 & 12 & 12 & 12 & 12 & 12 & 12 & 12 & 12 & 12 & 12 & 12 & 12 \\
\hline & CE & 12 & 12 & 12 & 12 & 12 & 17 & 12 & 12 & 12 & 12 & 12 & 12 & 12 & 12 & 12 & 12 & 12 & 12 & 12 & 12 & 12 & 12 & 12 & 12 & 12 & 12 & 12 \\
\hline & DF & 12 & 12 & 12 & 12 & 12 & 12 & 17 & 12 & 12 & 12 & 12 & 12 & 12 & 12 & 12 & 12 & 12 & 12 & 12 & 12 & 12 & 12 & 12 & 12 & 12 & 12 & 12 \\
\hline & ES & 12 & 12 & 12 & 12 & 12 & 12 & 12 & 17 & 12 & 12 & 12 & 12 & 12 & 12 & 12 & 12 & 12 & 12 & 12 & 12 & 12 & 12 & 12 & 12 & 12 & 12 & 12 \\
\hline & GO & 12 & 12 & 12 & 12 & 12 & 1 & 12 & 12 & 17 & 12 & 12 & 12 & 12 & 12 & 12 & 12 & 12 & 12 & 12 & 12 & 12 & 2 & 12 & 12 & 12 & 12 & 12 \\
\hline & MA & 12 & 12 & 12 & 12 & 12 & 12 & 12 & 12 & 12 & 17 & 12 & 12 & 12 & 12 & 12 & 12 & 12 & 12 & 12 & 12 & 12 & 12 & 12 & 12 & 12 & 12 & 12 \\
\hline & MT & 12 & 12 & 12 & 12 & 12 & 12 & 12 & 12 & 12 & 12 & 17 & 12 & 12 & 12 & 12 & 12 & 12 & 12 & 12 & 12 & 12 & 12 & 12 & 12 & 12 & 12 & 12 \\
\hline & MS & 12 & 12 & 12 & 12 & 12 & 12 & 12 & 12 & 12 & 12 & 12 & 17 & 12 & 12 & 12 & 12 & 12 & 12 & 12 & 12 & 12 & 12 & 12 & 12 & 12 & 12 & 12 \\
\hline & MG & 7 & 7 & 7 & 7 & 7 & 7 & 7 & 7 & 7 & 7 & 7 & 7 & 18 & 7 & 7 & 12 & 7 & 7 & 7 & 12 & 12 & 7 & 7 & 12 & 12 & 7 & 7 \\
\hline & PA & 12 & 12 & 12 & 12 & 12 & 12 & 12 & 12 & 12 & 12 & 12 & 12 & \begin{tabular}{|l|}
12 \\
\end{tabular} & 17 & 12 & 12 & 12 & 12 & 12 & 12 & 12 & 12 & 12 & 12 & 12 & 12 & 12 \\
\hline & PB & 12 & 12 & 12 & 12 & 12 & 12 & 12 & 12 & 12 & 12 & 12 & 12 & 12 & 12 & 17 & 12 & 12 & 12 & 12 & 12 & 12 & 12 & 12 & 12 & 12 & 12 & 12 \\
\hline & PR & 7 & 7 & 7 & 7 & 7 & 7 & 7 & 7 & 7 & 7 & 1 & 7 & 12 & 7 & 7 & 18 & 7 & 7 & 7 & 12 & 12 & 7 & 7 & 12 & 12 & 7 & 7 \\
\hline & PE & 12 & 12 & 12 & 12 & 12 & 12 & 12 & 12 & 12 & 12 & 12 & 12 & 12 & 12 & 12 & 12 & 17 & 12 & 12 & 12 & 12 & 12 & 12 & 12 & 12 & 12 & 12 \\
\hline & $\mathbf{P I}$ & 12 & 12 & 12 & 12 & 12 & 12 & 12 & 12 & 12 & 12 & 12 & 12 & 12 & 12 & 12 & 12 & 12 & 17 & 12 & 12 & 12 & 12 & 12 & 12 & 12 & 12 & 12 \\
\hline & $\mathrm{RN}$ & 12 & 12 & 12 & 12 & 12 & 12 & 12 & 12 & 12 & 12 & 12 & 12 & 12 & 12 & 12 & 12 & 12 & 12 & 17 & 12 & 12 & 12 & 12 & 12 & 12 & 12 & 12 \\
\hline & RS & 7 & 7 & 7 & 7 & 7 & 7 & 7 & 7 & 7 & 7 & 7 & 7 & 12 & 7 & 7 & 12 & 7 & 7 & 7 & 17 & 12 & 7 & 7 & 12 & 12 & 7 & 7 \\
\hline & RJ & 7 & 7 & 7 & 7 & 7 & 7 & 7 & 7 & 7 & 7 & 7 & 7 & 12 & 7 & 7 & 12 & 7 & 7 & 7 & 12 & 19 & 7 & 7 & 12 & 12 & 7 & 7 \\
\hline & Ro & 12 & 12 & 12 & 12 & 12 & 12 & 12 & 12 & 12 & 12 & 12 & 12 & 12 & 12 & 12 & 12 & 12 & 12 & 12 & 12 & 12 & 17 & 12 & 12 & 12 & 12 & 12 \\
\hline & $\mathbf{R R}$ & 12 & 12 & 12 & 12 & 12 & 12 & 12 & 12 & 12 & 12 & 12 & 12 & 12 & 12 & 12 & 12 & 12 & 12 & 12 & 12 & 12 & 12 & 17 & 12 & 12 & 12 & 12 \\
\hline & sc & 7 & 7 & 7 & 7 & 7 & 7 & 7 & 7 & 7 & 7 & 7 & 7 & 12 & 7 & 7 & 12 & 7 & 7 & 7 & 12 & 12 & 7 & 7 & 17 & 12 & 7 & 7 \\
\hline & SP & 7 & 7 & 7 & 7 & 7 & 7 & 7 & 7 & 7 & 7 & 7 & 7 & 12 & 7 & 7 & 12 & 7 & 7 & 7 & 12 & 12 & 7 & 7 & 12 & 18 & 7 & 7 \\
\hline & SE & 12 & 12 & 12 & 12 & 12 & 12 & 12 & 12 & 12 & 12 & 12 & 12 & 12 & 12 & 12 & 12 & 12 & 12 & 12 & 12 & 12 & 12 & 12 & 12 & 12 & 17 & 12 \\
\hline & TO & 12 & 12 & 12 & 12 & 12 & 12 & 12 & 12 & 12 & 12 & 12 & 12 & 12 & 12 & 12 & 12 & 12 & 12 & 12 & 12 & 12 & 12 & 12 & 12 & & 12 & 17 \\
\hline
\end{tabular}

\section{Quadro 1: Alíquota Estadual do ICMS}

\section{Fonte: FISCONTEX (2010).}

No Rio Grande do Norte, a lei ordinária 6.968/96 é quem dispõem sobre esse imposto de forte expressão de arrecadação do Estado. Já o Decreto N. ${ }^{\circ}$ 13.640/97 (Consolidado até Decreto $\mathrm{N}^{\mathrm{o}} 21.644 / 2010$ ) é o regulamento do imposto. É esse ultimo quem indicará os fatos geradores, as bases de cálculo, os contribuintes e o lançamento do imposto.

Nos arts. $1^{\circ}$ e $2^{\circ}$ desse dispositivo encontram-se os as incidências e os fatos geradores. Já as bases de cálculo estão dispostas nos arts. 69 ao 102, e as alíquotas no art.104 (a alíquota para mercadorias bens e serviços é de $17 \%$, nas operações internas, já nas operações interestaduais é de 12\%) do mesmo documento e são elaboradas de acordo com os fatos 
geradores. Essa alíquota pode ser seletiva, de acordo com a essencialidade do produto, como previsto pelo art. $155, \S 2^{\circ}$, III da $\mathrm{CF}$.

Os contribuintes do imposto são encontrados nas hipóteses do art. 146 do vigente decreto. Já o lançamento é realizado por homologação, previsto no art.118. Aspecto importante nesse regulamento é que a isenção nas operações e prestações relativas ao comércio exterior está disposta nos art.18 ao 22 do citado diploma.

Outra imunidade constitucional é a não incidência do IPI sobre produtos industrializados destinados ao exterior, definida pelo art. 153, $\S 3^{\circ}$, III da CF. Esse imposto é regulamentado pelo Decreto $N^{\circ} 4.544 / 2002$

Nesse decreto encontram-se os fatos geradores da referida exação, quais sejam: o desembaraço aduaneiro de produto de procedência estrangeira; ou a saída de produto do estabelecimento industrial, ou equiparado a industrial (art.34).

A alíquota incidente nesse imposto é uma alíquota seletiva, assim como ocorre com o ICMS, de acordo com a essencialidade dos produtos. Produtos cujo consumo seja indesejável, a exemplo de bebidas e cigarros, são taxados fortemente. As alíquotas variam de 0 a 330 por cento, mas a maioria dos produtos encontra-se abaixo de $20 \%$, de acordo com o sistema harmonizado, de acordo com Farias (2010).

Os produtos industrializados, nacionais e estrangeiros, ficam, dessa forma, sujeitos à incidência do imposto, de acordo com as especificações constantes da Tabela de Incidência do Imposto sobre Produtos Industrializados - TIPI (art. $2^{\circ}$, do decreto supra). Por força do artigo $153, \S 3^{\circ}$, II da Norma Maior, o IPI será não-cumulativo.

A base de cálculo dessa alíquota no caso dos produtos nacionais é o valor total da operação de que decorrer a saída do estabelecimento industrial ou equiparado a industrial adicionado (Inciso II do art.131 do decreto).

O valor total da operação compreende o preço do produto, acrescido do valor do frete e das demais despesas acessórias, cobradas ou debitadas pelo contribuinte ao comprador ou destinatário, de acordo com o $\S 1^{\circ}$ do art. 131 da citada regulamentação.

No art. 21 desse decreto encontramos os contribuintes de tal imposto. Já nos art. 122 e 123 do mesmo, está a forma de lançamento a ser realizado, a homologação.

A COFINS é uma contribuição social que se destina ao exclusivo financiamento das despesas com atividades-fim das áreas de saúde, previdência e assistência social. Ela é devida pelas pessoas jurídicas e as a elas equiparadas pela legislação do imposto de renda.

De acordo com o art. $7^{\circ}$ da Lei Complementar 70/91, as exportações são isentas desse tributo. Porém, essa isenção foi revogada pela Medida Provisória (MP) $n^{\circ}$ 2158-35, de 24.8.2001.

Na mesma medida provisória, no seu art. 14, está disposto que os fatos geradores, ocorridos a partir de 1o de fevereiro de 1999, são isentos da COFINS as receitas de vendas, com fim específico de exportação para o exterior, a empresas exportadoras registradas na Secretaria de Comércio Exterior do MDIC e também de vendas realizadas pelo produtor- 
vendedor às empresas comerciais exportadoras, desde que destinadas ao fim específico de exportação para o exterior.

Dessa maneira, esse artigo da Medida Provisória confirma a isenção do COFINS para as receitas de exportação direta, no primeiro caso, e exportação indireta, utilizando as comerciais exportadoras.

Hugo de Brito Machado (2004) nos ensina que a alíquota da COFINS é diferente conforme o regime de incidência. Se incidência cumulativa, a alíquota é de 3\%. Já se se tratar de incidência não-cumulativa, a alíquota será de 7,6\%. O seu lançamento será feito por homologação ou ex officio.Sua base de cálculo é feita pelo faturamento mensal (receita bruta da venda de bens e serviços), ou pelo total das receitas da pessoa jurídica.

O PIS é uma contribuição destinada a financiar o programa de seguro-desemprego e o abono anual aos empregados. De acordo com o com o art. 14, § $1^{\circ}$, da MP 2.158-35/2001, as exportações são isentas dessa contribuição.

De acordo com o art. $2^{\circ}$ do Decreto $\mathrm{n}^{\circ} 4.524 / 2002$ o PIS/Pasep tem como fato gerador o auferimento de receita pela pessoa jurídica de direito privado e no caso das entidades relacionadas no art. $9^{\circ}$ do mesmo dispositivo a folha salarial dessas entidades.

O contribuinte é o mesmo da COFINS, pessoas jurídicas e as a elas equiparadas pela legislação do imposto de renda. Suas alíquotas são de $0,65 \%$ cumulativamente e de 1,65\% não cumulativamente.

O IOF, Imposto sobre Operações de Crédito, Câmbio e Seguro ou relativas a Títulos ou Valores Mobiliários (ou Imposto sobre Operações Financeiras), é utilizado como um instrumento de política de Crédito, Câmbio e Seguro e Transferência de Valores.

Por conseguinte, tem como fato gerador as operações de crédito, câmbio e seguro ou relativas a Títulos ou Valores Mobiliários, de acordo com a Constituição Federal, art. 154, V. O art.63 do CTN enumera as hipóteses de incidência, enquanto o art. $2^{\circ}$ do Decreto presidencial $n^{\circ}$ 4.494/2002 enquadra as incidências.

O imposto tem como fato gerador a entrega do montante ou do valor que constitua o objeto da obrigação, ou sua colocação à disposição do interessado, de acordo com o art $3^{\circ}$ do Decreto 4.494/2002. De acordo com o art. $4^{\circ}$ dessa lei, são seus contribuintes as pessoas físicas ou jurídicas tomadoras de crédito.

De acordo com o art. $6^{\circ}$ do referido decreto, o IOF será cobrado à alíquota máxima de $1,5 \%$ ao dia sobre o valor das operações de crédito, quando não estiver na hipótese da alíquota reduzida prevista no art. $7^{\circ}$ do mesmo dispositivo.

$\mathrm{O}$ art. $8^{\circ}$ desse decreto beneficia os exportadores ao tornar a alíquota zero na operação de crédito à exportação, bem como de amparo à produção ou estímulo à exportação.

Como já exposto anteriormente e adicionando a colaboração de Harada (2003) a Alíquota zero, é uma operação tributada, mas que produz o mesmo efeito de isenção e com ela se confunde, no que concerne à finalidade de outorgar um privilégio tributário. Dessa 
maneira, cumpre o seu papel extrafiscal com vistas à implementação de determinada produção de interesse nacional.

Dessa maneira, há incidência de alíquota, porém alíquota zero, não contabilizando em custos para o empresariado.

Fazendo um apanhado geral, concluímos as seguintes alíquotas dos tributos:

Tabela 6: Alíquotas Tributária não Incidentes na Exportação

\begin{tabular}{ccc}
\hline Tributo & Alíquota \\
\hline ICMS Interno RN & $17 \%$ \\
COFINS & $7,6 \%$ \\
PIS & $1,65 \%$ \\
IOF & $1,50 \%$ \\
Média IPI & $17 \%$ \\
\hline
\end{tabular}

Fonte: O Autor (2010).

Vale ressaltar que as alíquotas do PIS e COFINS podem ter regime de incidência cumulativo, mudando para $0,65 \%$ e $3 \%$ do valor da receita ou faturamento da empresa, respectivamente.

Outro ponto que deve ser ressaltado é que o ICMS e o IPI são impostos de alíquota seletiva, ou seja, sua alíquota varia de acordo com a essencialidade do produto. Assim exposto, faz-se necessário verificar a alíquota específica de cada produto.

Por fim, há de se ressaltar que nem sempre o IOF incide sobre uma operação de comercialização, podendo sua alíquota ser contabilizada ou não, ao contabilizar os impostos incidentes.

Dessa maneira, foi-se listada as alíquotas dos impostos e contribuições sociais, que incidem sobre uma operação comercial brasileira, mas não sobre uma operação de exportação, de modo a visualizar a quantidade de impostos que não são exportados junto ao produto.

Esses incentivos são apresentados ao exportador com o intuito de não se exportar tributos, de fortalecer a competitividade do produto nacional no mercado externo e fazer com que ele possa se inserir e disputar um amplo mercado, que é o mercado global.

Agora estudaremos o instituto da não cumulatividade e o sistema de presunção de créditos que permitem tais incentivos tributários ao exportador. 


\section{DO INSTITUTO DA NÃO-CUMULATIVIDADE}

Nos artigos $153, \S 3^{\circ}$, II e $155, \S 2^{\circ}$, I, a Constituição Federal estabelece o instituto da nãocumulatividade em relação ao IPI e ICMS. De tal forma que, será compensado o que for devido em cada operação relativa aos fatos geradores. Estes artigos são normas de eficácia plena e imediata, instituindo a não-cumulatividade como regra ou princípio a ser observado, sem restrições, pelo legislador infraconstitucional. (MACHADO, 2010)

Ora, sabe-se que o IPI e o ICMS são conhecidos como tributos que incidem sobre a circulação de bens e serviços em inúmeras etapas da cadeia econômica, ou seja, a tributação destes impostos pressupõe operações de uma mesma cadeia produtiva ou circulatória de bens e serviços.

Uma vez que o foco central da produção, circulação e prestação de serviços é o consumidor final, sendo evidente que as atividades dos produtores, industriais, comerciantes e prestadores de serviços direcionam-se à essa população, a nãocumulatividade significa um sistema operacional que tem como principal objetivo minimizar a carga tributária incidente sobre as operações realizadas com produtos, mercadorias e serviços, tendo por finalidade diminuir o preço que repercute na diminuição do custo de vida, possibilitando a geração de emprego, realização de investimentos empresariais e outras medidas benéficas ao desenvolvimento econômico.(MELLO, 2004)

No caso de ciclo econômico composto de várias etapas, a incidência de um imposto em uma operação servirá como base de cálculo do imposto incidente na etapa posterior, gerando a cumulatividade da tributação. A não-cumulatividade visa justamente evitar esse efeito "cascata" da tributação destes impostos.

A não-cumulatividade deverá ser observada em todo o ciclo operacional, que não pode sofrer supressão parcial, face aos princípios da isonomia e da capacidade contributiva de cada um dos agentes empresariais. (MACHADO, 2010).

A não-cumulatividade é alcançada através da técnica de compensação de débitos com créditos ou o sistema de créditos e débitos, no qual o contribuinte recolhe periodicamente a diferença entre os tributos não cumulativos incidentes sobre suas vendas e o total a que se creditou face às suas aquisições.

Ensina-nos Paulo Werneck, que no caso da exportação, a empresa paga o ICMS dos seus produtos, dessa maneira, há a aquisição dos créditos nesses gastos, haja vistas a desoneração na exportação. Dessa maneira, compensam-se esses créditos quando se faz o recolhimento do tributo devido nas vendas do produto final no mercado interno.

Já o IPI, segue o mesmo sistema de créditos e débitos, ou sistema de presunção de crédito. As empresas exportadoras terão direito ao crédito do IPI pago nas aquisições de matérias primas, produtos intermediários e materiais de embalagem efetivamente utilizado no processo produtivo dos bens industrializados destinados à exportação. Dessa sistemática surge um dos problemas do sistema de créditos e débitos que se dá no momento em que os créditos se acumulam (numa hipótese de exportações maiores que vendas internas).

Em se tratando de ICMS, uma solução é não utilizar a presunção de crédito desse sistema, mas sim o recolhimento do crédito, obtido através de autorização expressa da Secretaria 
Estadual da Fazenda, baseado na análise do processo produtivo e no compromisso da exportação. (WERNECK, 2007)

Uma outra solução é o repasse do crédito acumulado para outros contribuintes do mesmo estado, mesmo que seja outro estabelecimento da empresa, mediante a emissão pela Secretária Estadual da Fazenda de documento reconhecendo tal crédito. Essa possibilidade surgiu com a Lei complementar $n^{\circ} 87 / 96$, Lei Kandir.

O mesmo problema surge no caso do acúmulo de créditos do IPI. A solução é, se no fim de cada trimestre-calendário, a empresa não utilizar tal crédito, a mesma poderá requerer à Receita Federal o ressarcimento em espécie ou utilizar o crédito para compensar os débitos dos demais tributos ou contribuições administrados pela SFR.

Machado (2010), ensina-nos que em se tratando de PIS/COFINS, o sistema de nãocumulatividade, é distinta daquela estabelecida do sistema existente para o IPI e o ICMS. Trata-se de sistemática jurídica da incidência distinta.

O critério quantitativo do PIS e da COFINS diz respeito à "totalidade das receitas auferidas", que é fenômeno relacionado à pessoa do contribuinte (empresa jurídica), não possuindo qualquer identidade com algum fenômeno circulatório, traço característico originário do IPI e do ICMS. (MACHADO, 2010)

A não-cumulatividade do PIS e da COFINS é operada mediante redução da base de cálculo, com a respectiva dedução de créditos relativos às contribuições que foram recolhidas sobre bens e/ou serviços objeto de faturamento em etapas anteriores, permitindo, assim, minorar os efeitos resultantes da tributação sobre o faturamento ou receita do contribuinte, incentivando determinadas atividades econômicas e desonerando os efeitos da incidência sobre o faturamento.

O autor critica o fato do regime não-cumulativo para o PIS e a COFINS estabelecer a aplicação única de uma alíquota nominal mais elevada, se comparada com o regime cumulativo dessas contribuições. Critica também as várias restrições ao crédito pelas Leis $\mathrm{n}^{\mathrm{o}} 10.637 / 02$ e 10.833/03, que provocam um efetivo aumento da carga tributária para praticamente todos os contribuintes sujeitos à nova sistemática.

O mesmo defende que o objetivo da não-cumulatividade estabelecida para as contribuições do PIS e COFINS é a diminuição da tributação sobre o faturamento, no qual o legislador infraconstitucional deveria obedecer rigorosamente este princípio nos casos definidos em lei.

Porém, o problema está na concessão e aplicação de uma sistemática que na verdade não revela ser mais benéfica a determinados contribuintes, como parecia à primeira vista, revelando uma série de prejuízos aos princípios constitucionais, de forma que tal sistemática não coaduna com o propósito da incidência não-cumulativa, que é evitar a incidência em cascata.

Ele afirma que a sistemática não-cumulativa gerou um aumento das receitas tributárias do Estado, mas ao mesmo tempo ela restringe o desenvolvimento econômico das empresas responsáveis pelo crescimento sustentável do País. Ou seja, de acordo com o autor, é uma ferramenta ineficiente e ineficaz. 


\section{INEFICIÊNCIA DO SISTEMA DA DESONERAÇÃO TRIBUTÁRIA}

De acordo com Werneck (2007), a não cobrança de tributos sobre a exportação não é respeitada pela legislação tributária brasileira, mesmo considerando todas as imunidades e isenções. O sistema de crédito presumido não atende todas as fases do processo produtivo e as isenções, suspensões e créditos implicam na exigência de obrigações acessórias que também oneram o exportador.

Dessa forma, mesmo com a desoneração tributária, grande parte dos exportadores reiteram, de acordo com pesquisa feita pela Confederação Nacional da Indústria, a afirmação de Werneck, que os tributos afetam negativamente a competitividade externa dos produtos brasileiros, haja vista que os mecanismos de desoneração não são eficientes.(CNI, 2008)

Por exemplo, devido à sua incidência em cascata, total ou parcial, na cadeia produtiva, alguns tributos não são desonerados, confirmando a ineficiência dessa desoneração. Além disso, existe uma série de mecanismos complexos e demorados que criam custos adicionais às empresas. Podemos assim, apontar a não eficiência do sistema de crédito presumido como fator limitante à competitividade do produto nacional no exterior essa excessiva burocracia.

Outro fator limitante, levantado nessa pesquisa é a incidência de outros tributos que não estão enquadrados na desoneração. Podemos citar como exemplos o Imposto de Renda de Pessoa Jurídica (IRPJ), a Contribuição Social sobre o Lucro Líquido (CSLL) e os encargos trabalhistas. Dessa forma, mesmo se o sistema de presunção de crédito tivesse plena eficiência, ainda residiria parte da onerosa carga tributária brasileira que influenciam na competitividade externa dos produtos brasileiros.

Outro agravante se dá em relação ao não conhecimento, por parte dos empresários, dos mecanismos de ressarcimento de tributos, desconhecido principalmente entre as microempresas e aquelas que não estão acostumadas com o processo exportador, o que demonstra a importância de profissionais que lidem com o processo de exportação da empresa e consequentemente da legislação aduaneira. (CNI, 2008)

Além de não conhecimento, aqueles que conhecem o processo de exportação e que já possuem uma carga de conhecimento da sistemática de comércio exterior reclamam do sistema tributário nacional em relação ao ressarcimento, sua demora, tanto na homologação do pedido de compensação quanto na demora no ressarcimento do crédito em espécie.

Dessa forma, adota-se posição semelhante ao de Werneck, ao defender além da busca pela eficiência do sistema de crédito presumido, fazendo com que tal mecanismo exerça corretamente a sua função de evitar a cumulatividade dos tributos, a racionalização do sistema tributário através de uma futura reforma tributária que reduzisse a carga tributária, e realmente desonerasse o exportador e estimulasse a economia.

\section{FATORES INTERVENIENTES NA FORMAÇÃO DE PREÇO}

Em relação à formação de preços, há de se verificar a importância da estrutura de custos de uma empresa. Mayer (2006) faz um resumo do que os autores consideram como despesas exclusivas do mercado interno e os dispêndios exclusivos do mercado externo. 
Dessa forma, para a primeira fase da formulação do preço da exportação, basta subtrair ao preço do produto no mercado nacional, as despesas exclusivas do mercado interno, no qual está incluída a desoneração fiscal.

A próxima etapa para se alcançar o preço da exportação é adicionar ao preço do produto, sem os encargos exclusivamente nacionais, as despesas exclusivas do mercado externo. Segue abaixo o trabalho da autora que demonstra quais são as despesas citadas pela doutrina do comércio exterior.

\begin{tabular}{|c|c|c|}
\hline Autor & $\begin{array}{l}\text { Despesas exclusivas do } \\
\text { Mercado Interno }\end{array}$ & $\begin{array}{l}\text { Despesas exclusivas do } \\
\text { Mercado Externo }\end{array}$ \\
\hline Garcia (2001) & 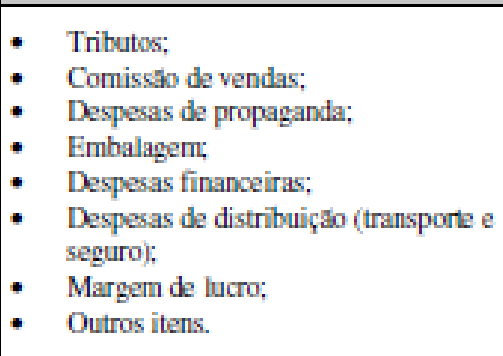 & 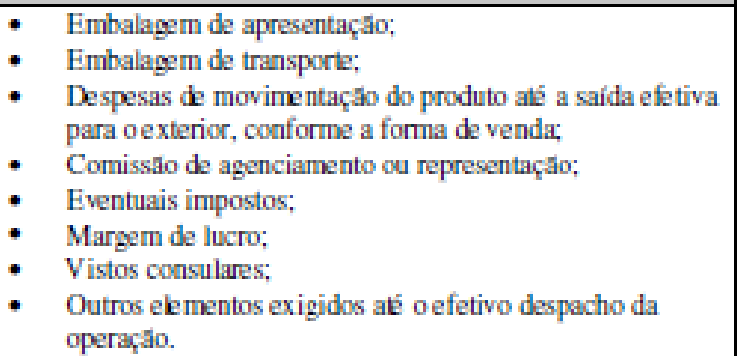 \\
\hline Ratti (2000) & 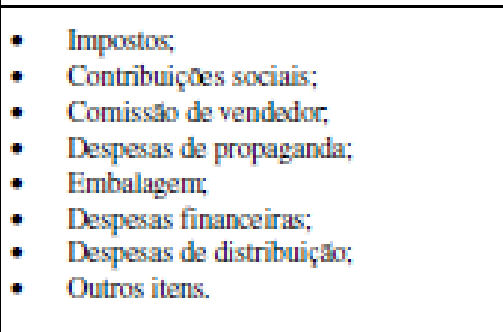 & $\begin{array}{l}\text { - Comissăo de agente ou representante no ex terior, } \\
\text { - Embalagem de apresentaçăo e de acondicionamento, } \\
\text { - Despesas de movimentaçăo do produto - frete e seguro } \\
\text { intemo; } \\
\text { - Despesas financeiras, desde a produçăio, estocageme } \\
\text { embarque; } \\
\text { - Fatura e ou vistos consulares; } \\
\text { - Eventuais impostos; } \\
\text { - Outros itens }\end{array}$ \\
\hline Lopez (2000) & $\begin{array}{l}\text { - Custos de fabricaçăo; } \\
\text { - Custos logísticos, } \\
\text { - Outros custos. }\end{array}$ & $\begin{array}{l}\text { - Custos de fabricaçăo; } \\
\text { - Custos logísticos - consideram-se os custos pós } \\
\text { fabricaçăa, ou seja, diretamente ligados à distribuiçăo } \\
\text { física, incluindo pesquisa de mercado, negociaçăo } \\
\text { intemacional, acondicionamento, transporte interno, } \\
\text { movimentaçăo no tenninal de embarque; } \\
\text { - Outros custos. }\end{array}$ \\
\hline $\begin{array}{c}\text { Minervini } \\
\text { (1997) }\end{array}$ & - Nåo citado pelo autor & 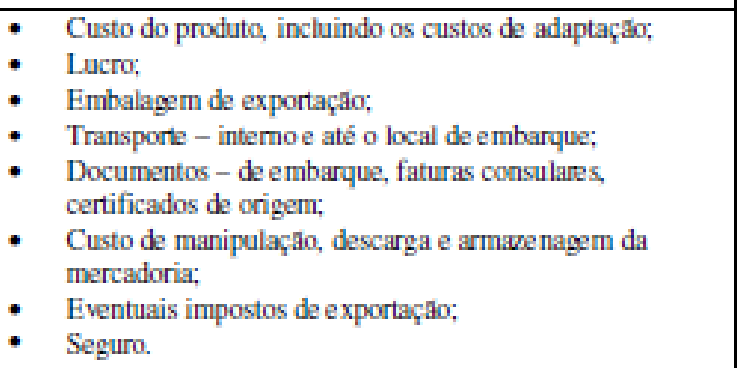 \\
\hline Maluf (2000) & - Náo citado pela autora & $\begin{array}{l}\text { - } \quad \text { Custos de produçắ; } \\
\text { - } \quad \text { Custos da estrutura de ex portaçăo; } \\
\text { - } \quad \text { Custos de distribuiçăă; } \\
\text { - Custos de promoçăo; } \\
\text { - Custos vanáveis. }\end{array}$ \\
\hline
\end{tabular}

Quadro 2: Despesas incidentes no mercado interno ou no mercado externo. Fonte: MEYER (2006). 
Analisa-se em tal quadro que não há divergências na doutrina no tocante aos elementos que incidem no mercado interno e aqueles que incidem no mercado externo. Nos elementos internos, há a convergência quanto os custos de fabricação (tributos, comissões, margens de lucro), os custos logísticos (embalagem, despesas de distribuição, frete, seguro, design), além de custos com despesas de propaganda e despesas financeiras.

Já os elementos externos podem ser resumidos aos seguintes custos: da estrutura de exportação (comissões, margem de lucro, eventuais impostos, documentação, despacho, custos de promoção); logísticos (embalagem especial de apresentação e de transporte, despesas de distribuição, frete, seguro); e os diversos gastos. Todas essas despesas irão variar de acordo com incoterm utilizado e a forma de venda.

Tentar formular esses custos de forma a encontrar um parâmetro a ser utilizado diametralmente por todas as empresas, de qualquer porte, que comercialize qualquer produto ou que atue em qualquer lugar, é impossível. Assim, o caso empírico que vai determinar quais gastos incidirá ou não na formação de preço do produto nacional.

Tal formula dependeria das seguintes variáveis: o domínio da estrutura interna, dos incentivos e benefícios disponíveis no mercado; o poder de barganha em relação aos diversos agentes de comércio exterior; a ciência e utilização de acordos internacionais existentes, a melhor logística e os incoterms mais apropriados, entre outros.

Dessa forma, a segunda fase da formulação do preço, é ter conhecimento dessas inconstantes e utilizá-las de forma a desonerar mais ainda o produto ou de criar uma vantagem competitiva em relação aos outros produtos disponíveis no mercado. Um melhor preço, uma melhor condição de venda, uma venda mais simplificadas são diferenciais que favorecem a empresa no cenário internacional.

Seguindo-se a recomendação governamental, em relação à elaboração da tabela de formação de preço, utilizou-se o modelo de tabela fornecido no sítio do aprendendo a exportar (BRASIL, 2010). Utilizou-se como base o preço FOB, por ser o modelo mais empregado em se tratando de exportações. Chegou-se ao seguinte modelo: 


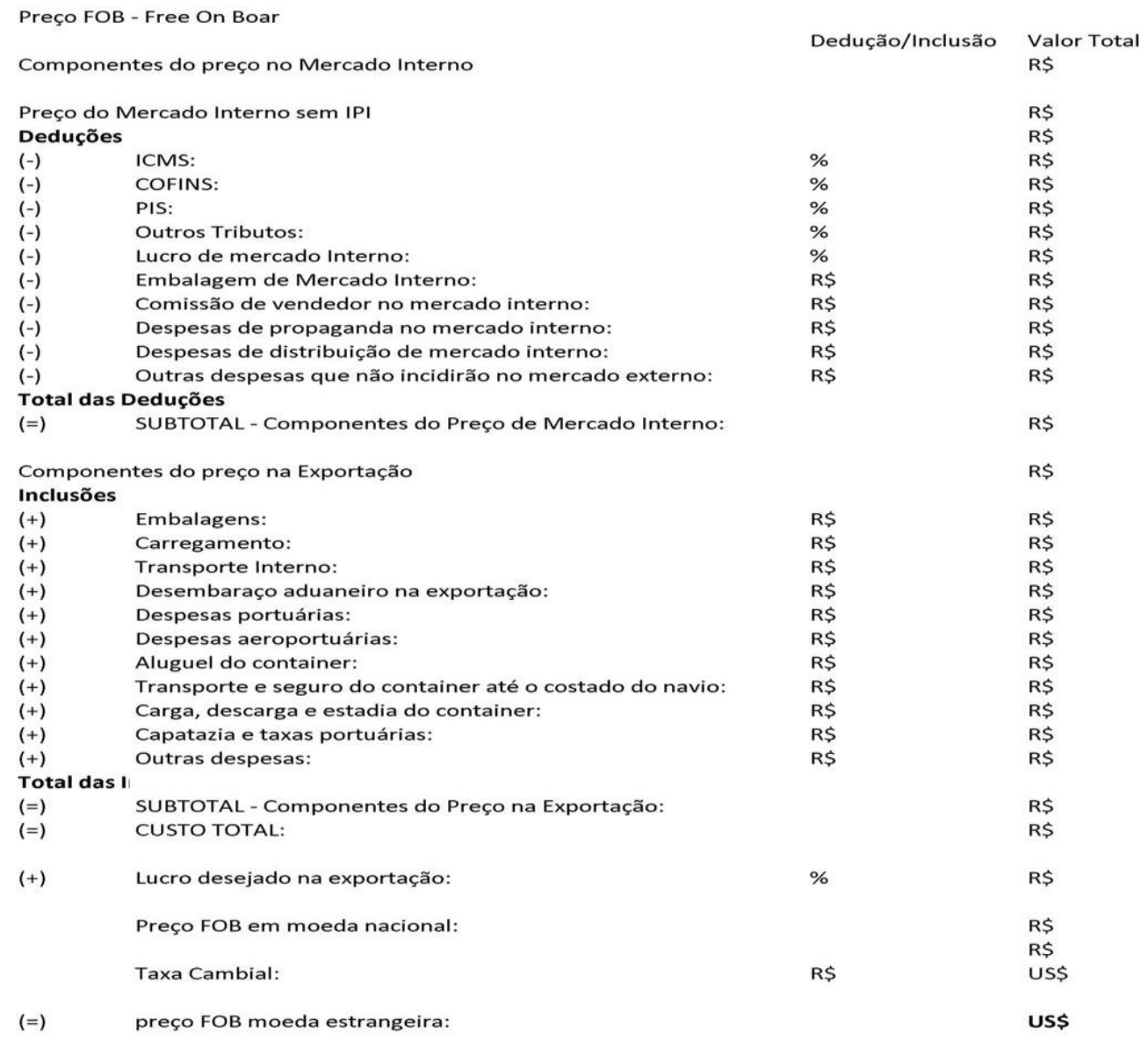

\section{Quadro 3: Modelo de Formação de Preço. Fonte: adaptado (Brasil, 2010).}

O modelo corrobora com o sistema de dedução de gastos exclusivamente nacional e a inclusão de gastos exclusivamente internacionais já explicados acima e auxiliado pela tabela 4, formulada por Mayer (2006), a partir da doutrina da área de Comércio Exterior.

Importante destaque se faz à dedução dos impostos, tema do trabalho. Verifica-se que até em relação aos impostos, é impossível chegar a um valor único a ser desonerado para todos os produtos, que sirva igualmente a todas as empresas, haja vista o instituto da seletividade dos tributos IPI e ICMS, cuja alíquota depende da essencialidade do produto, o fato do ICMS ser um imposto estadual, cuja alíquota irá variar de estado a estado e a incidência ou não do IOF, dependendo da utilização das operações financeiras da empresa.

Vale ressaltar que nas operações de exportações é comum o uso da alíquota não cumulativa, as alíquotas comumente utilizadas no PIS e no COFINS serão as alíquotas não-cumulativas, tendo em vista a dificuldade do cálculo, na base de cálculo da alíquota cumulativa. Dessa maneira, o empresário utilizará o já discutido sistema de presunção de créditos. Utilizando-se dessa maneira, como o modelo de formação de preço, a alíquota do PIS e COFINS não-cumulativas.

Outro fato que merece destaque são as diferenças da venda para o mercado interno e a venda para o mercado externo. Em relação às embalagens, as exigências dos países serão 
distintas, seja a embalagem de apresentação, que irá informar as qualidades de tal produto, seja a embalagem transporte, feito para a proteção e conservação do produto.

Estamos tratando de comércio exterior, dessa forma abordamos diversas culturas, e muitas vezes longas distâncias, no qual o prazo temporal será maior, exigindo embalagens mais resistentes. Assim, a empresa tem que adequar o produto à essas particularidades, bem como às exigências feitas por parte dos compradores, majorando, na maioria das vezes, os custos com embalagem.

Em relação às comissões, também parece ser algo lógico que haja tal distinção. A venda, a propaganda e distribuição do mercado interno são diferentes em relação ao mercado externo. Envolvem atores diversos que irão exigir, consequentemente, diferentes comissões e gerará distintos gastos para a empresa. Os dispêndios com a distribuição envolvem diversos novos procedimentos, como o desembaraço aduaneiro, as diversas despesas aeroportuários, dependendo do modal a ser utilizado e do incoterm negociado entre as partes.

No livro Exportação passo a passo (BRASIL, 2004), do Ministério das Relações Exteriores, é fornecido um exemplo prático da utilização do modelo exibido anteriormente, provido pelo sítio Aprendendo a Exportar MRE. 
FREITAS \& MEIRELES (2010)

\begin{tabular}{|c|c|}
\hline ITENS & VALOR \\
\hline Preço de mercado interno sem o IPI (Para efeito de cálculo das deduções) & $\mathrm{R} \$ 5.000,00$ \\
\hline Preço de mercado interno (inclusive IPI de 14\%) & $\mathrm{R} \$ 5.700,00$ \\
\hline \multicolumn{2}{|l|}{ Deduções } \\
\hline IPI (14\% sobre o preço de mercado sem IPI) & $\mathrm{R} \$ 700,00$ \\
\hline ICMS (18\% sobre o preço de mercado sem IPI) & $\mathrm{R} \$ 900,00$ \\
\hline COFINS ( $7,6 \%$ sobre o preço de mercado sem IPI) & $\mathrm{R} \$ 380,00$ \\
\hline PIS (1,65\% sobre o preço de mercado sem IPI) & $\mathrm{R} \$ 82,50$ \\
\hline Lucro no mercado interno ( $10 \%$ sobre o preço de mercado sem IPI) & $\mathrm{R} \$ 500,00$ \\
\hline Embalagem de mercado interno & $\mathrm{R} \$ 40,00$ \\
\hline Total das deduções & $\mathbf{R} \$ 2.602,50$ \\
\hline $\begin{array}{c}\text { Primeiro Subtotal (Diferença entre o preço com o IPI R } \$ 5.700,00 \text { e o total de } \\
\text { deduções } R \$ 2.602,50 \text { ) }\end{array}$ & $\mathrm{R} \$ 3.097,50$ \\
\hline \multicolumn{2}{|l|}{ Inclusões } \\
\hline Embalagem de exportação & $\mathrm{R} \$ 55,00$ \\
\hline Frete e seguro da fábrica ao local de embarque & $\mathrm{R} \$ 100,00$ \\
\hline Total das inclusões & $\mathbf{R} \$ 155,00$ \\
\hline $\begin{array}{l}\text { Segundo subtotal (Soma do primeiro subtotal } \mathrm{R} \$ 3.097,50 \text { com o total das } \\
\text { inclusões } \mathrm{R} \$ 155,00 \text { ) }\end{array}$ & $\mathrm{R} \$ 3.252,50$ \\
\hline Margem de lucro pretendida ( $15 \%$ calculado sobre o preço FOB) & $\mathrm{R} \$ 573,97$ \\
\hline Preço FOB $(\mathrm{R} \$ 3.252,50$ mais $\mathrm{R} \$ 573,97)$ & $\mathrm{R} \$ 3.826,47$ \\
\hline \multicolumn{2}{|l|}{ Tomando-se uma taxa de câmbio hipotética de US\$1,00 $=\mathrm{R} \$ 2,90$} \\
\hline Tem-se o preço FOB de & US\$ $1,319.47$ \\
\hline
\end{tabular}

\section{Quadro 4: Exemplo de Formação de Preço Fonte: Brasil (2004).}

Esse exemplo, apesar de simplificado, ajuda a visualizar como utilizar o modelo proposto pelo sítio aprendendo a exportar.

Dessa forma, chega-se, no exemplo institucional, a uma diferença entre o preço nacional e preço internacional do modelo de $67 \%$ (Diferença de $\mathrm{R} \$ 5.700,00$ e $\mathrm{R} \$ 3.826,47$ ), o que sem dúvidas se traduz num enorme aumento de competitividade no mercado internacional. Dessa diferença, pode-se averiguar que no exemplo, $41,25 \%$ são provenientes da desoneração tributária, soma da dedução dos tributos no exemplo, corroborando pra a afirmação que a carga tributária nacional é excessivamente onerosa.

Em relação aos demais termos internacionais de comércio, utiliza-se a proposta de Lopez (2007), de empregar os incoterms EXW, FOB, CIF e DDP, para a formação de preço e 
adiciona-se as condições FCA e CIP, para abranger os demais modais de transporte, que são limitados nos termos FOB e CIF (esses termos admitem apenas o modal marítimo). Segue em apêndice, o modelo de formulação dos demais incoterms.

A principal diferença entre a formação de preço desses incoterms são as obrigações que o exportador irá assumir ou não ao longo do processo, no qual no caso de um EXW ele terá as mínimas obrigações possíveis, disponibilizando a mercadoria no estabelecimento do exportador, deixando à cargo do importador o desembaraço aduaneiro e as demais formalidades alfandegárias e no caso do DDP, o exportador arcará com o máximo de responsabilidades, entregando a mercadoria já desembaraçada no local de destino designado pelo importador.

Consequentemente, o preço de um produto no incoterm EXW será menor, para o exportador, do que o preço de uma mercadoria no incoterm DDP. Por fim, utiliza-se o incoterm de acordo com o poder de barganha das partes entre elas, e entre os diversos agentes de comércio exterior que serão envolvidos na comercialização internacional, como o despachante, o agente de cargas, o armador, a seguradora, etc.

\section{CONSIDERAÇÕES FINAIS}

Após a análise do sistema tributário brasileiro - e de sua afirmada pesada carga de exações, que chega a atingir quase $40 \%$ da soma de todas as riquezas produzidas no Brasil verificou-se uma política de desoneração dos impostos ditos de consumo, na exportação dos produtos nacionais, de forma a torná-los competitivos no mercado externo e como forma de não exportar essa carga tributária onerosa para o consumidor estrangeiro.

Dessa maneira, verificou-se que a desoneração de IPI, ICMS, PIS, COFINS e IOF constitui uma artifício nacional de estimulo às exportações, em razão dos benefícios gerados pela mesma à economia pátria. Essa desoneração, em termos médios e gerais, estaria na ordem de $44,75 \%$ do preço final do produto a ser exportado, somado os tributos não incidentes na exportações disponível na tabela 6 , pág. 45 do presente trabalho.

Apesar da pouca participação do Brasil nas exportações mundiais (em torno de 1,17\%, em 2007 de acordo com o MDIC/SECEX), o Brasil vem aumentando sua representatividade internacional, além de majorar a importância do seu desempenho exportador na economia interna, graças ao estímulo tributário e a outros incentivos à exportação como a crescente desburocratização dos procedimentos e operações do comércio exterior; o estímulo especial à internacionalização das micro e pequenas empresas; e os diversos acordos comerciais realizados favorecendo as relações comerciais entre países.

Entretanto, ao analisar a forma como tais impostos são desonerados, estudou-se o sistema de não cumulatividade, e o sistema de presunção de crédito ou de compensação de créditos e débitos e verificou-se uma série de problemas causados pela sistemática da tributação nacional, no qual o aparelho tributário empírico e a burocracia tornam o sistema ineficiente, particularmente em relação ao sistema da compensação de créditos e débitos.

Portanto, chegamos à conclusão que tal sistema deve ser aperfeiçoado, para que o sistema de crédito presumido alcance a sua finalidade, que é o de evitar o efeito cascata da tributação e o de desonerar os exportadores nacionais. 
Além da ineficiência do sistema de presunção de crédito, encontraram-se outras falhas na sistemática da desoneração fiscal, a exemplo do acúmulo de crédito por parte dos empresários que mais exportam do que comercializam no mercado interno.

São problemas que possuem soluções, mas que envolvem mecanismos complexos e demorados que geram obrigações acessórias aumentando os custos da empresa, e consequentemente, o preço final do produto, influenciando negativamente na tomada de decisões do empresário em relação à exportação do seu produto.

Verificou-se com o estudo que a tomada de decisão do empresário, que visa exportar, e a competitividade do seu produto no mercado internacional, dependem de uma série de fatores externos e internos à empresa. É dada importância ao processo de formação de preço para a exportação, que será um planejamento da viabilidade da exportação deste. Nesse processo, o conhecimento das variáveis externas e internas, limitantes e estimuladoras, é essencial ao administrador da empresa, de modo a buscar as melhores condições de venda da mercadoria.

Variáveis como incidência ou não incidência de tributos, acordos internacionais, exigências comerciais exógenas, poder de barganha com os diversos agentes que atuam no comércio exterior, políticas locais, estaduais, nacionais e estrangeiras estimuladoras ou limitantes ao comércio exterior, são fatores que o tomador de decisão tem que ter pleno conhecimento, de forma a não inviabilizar o negócio. São variáveis que afetam o custo final do produto, mas para as quais não se sabe o seu grau de influência nesse processo.

Dessa forma, o empresário tem que levar em conta no processo de formação de preço: a estrutura de custos internos e dos gastos exclusivos do mercado local; as peculiaridades dos mercados externos e suas inúmeras variáveis; além de ter a percepção e síntese desses fatores, para bem formar o seu preço e o seu processo de internacionalização.

Assim, destaque especial se faz ao operador do comércio exterior, profissional especializado e importante em todos os processos onde atua. É ele quem vai processar todas as informações da área onde atua, transformando-as em conhecimento, em vantagem competitiva. No caso empresarial, é ele quem irá viabilizar os objetivos da empresa, terá o conhecimento dos mecanismos, das variáveis limitantes ou estimuladoras do comércio exterior e irá gerar e gerenciar o processo de adequação à internacionalização da empresa.

Ao reconhecer a importância do profissional da área, sugere-se ao meio acadêmico, a elaboração de maiores estudos nos campos da formação de preço e da desoneração tributária na exportação, de forma a complementar a homogênea pesquisa de formação de preço elaborada por parte dos doutrinadores da área de comércio exterior, bem como procurar maneiras de reestruturar o ineficiente sistema de desoneração tributária.

Sugere-se, também, à organização estatal e ao ordenamento jurídico, maior celeridade aos processos que envolvem o comércio exterior, diminuindo-se, assim, a excessiva burocracia existente, que retarda a competitividade nacional no cenário internacional, bem como as exportações brasileiras. Ademais, sugere-se a reforma do sistema tributário, de forma a diminuir a excessiva carga tributária nacional, acreditando com isso, estimular a economia e os investimentos dos empresários nacionais, a geração de emprego e o desenvolvimento econômico. 
Por fim, procurou-se com a pesquisa estabelecer parâmetros para a formação de preços e a busca pela máxima competitividade dos produtos nacionais no mercado internacional em reconhecimento à importância do comércio exterior em uma economia, em particular a importância das exportações, como estimulador do desenvolvimento econômico do país.

Tal parâmetro é impossível de ser encontrado, haja vista à enorme quantidade de variáveis, internas ou externas, que estimulam ou limitam a competitividade nacional, no mercado externo. É impraticável encontrar um consenso sobre tais fatores intervenientes, uma vez que a formação de preço transcende uma análise matemática simples, e se posiciona num contexto mais abrangente.

Espera-se que o trabalho colabore no ponto de vista social, econômico e acadêmico, estimulando a inserção de novas empresas no comércio exterior, em particular, às micro e pequenas empresas, que merecem uma maior atenção em relação às grandes empresas; desperte também novos trabalhos nessa instigante e complexa área; e impulsione políticas estimuladoras do comércio exterior brasileiro.

\section{REFERÊNCIAS}

1. ANGHER, A. J. Vade mecum acadêmcico de direito. São Paulo: Rideel, 2009

2. BANCO CENTRAL DO BRASIL. Evolução do PIB brasileiro. Somente il. Brasilia: BACEN, [200-?]. Disponível em: <www.bacen.gov.br> . Acesso em: 10 dez. 2009.

3. BONFIM, Paulo Andreatto. Inexistência do direito ao crédito do IPI decorrente de operações isentas, imunes ou sujeitas à alíquota zero . Jus Navigandi, Teresina, ano 8, n. 447, 27 set. 2004. Disponível em:

<http://jus2.uol.com.br/doutrina/texto.asp?id=5739>. Acesso em: 10 jun. 2010.

4. BRASIL. Senado Federal. Constituição da República Federativa do Brasil. Brasília: Senado Federal, 1988.

5. _. Lei $\mathrm{n}^{\circ} 5.172$, de 25 de outubro de 1966. Dispõe sobre o Sistema Tributário Nacional e institui normas gerais de direito tributário aplicáveis à União, Estados e Municípios. Lex: Coletânea de Legislação e Jurisprudência. Legislação Federal e marginalia, São Paulo, 1966

6. _. Ministério das Relações Exteriores. Divisão de programas de promoção comercial: exportação passo a passo. Brasília: MRE. 2004.

7. _. Ministério do Desenvolvimento, Indústria e Comércio Exterior. Disponível em: 〈www.mdic.gov.br>. Acesso em: $10 \mathrm{dez}$. 2009a.

8.

. Ministério do Desenvolvimento, Indústria e Comércio Exterior. Secretaria de Comércio Exterior, Estratégia Brasileira de Exportação 2008. Brasília, 2008a.

9. . Ministério do Desenvolvimento, Indústria e Comércio Exterior.

Aprendendo a Exportar. Brasilia, [200-?]. Disponível em: < www.aprendendoaexportar.gov.br>. Acesso em: 13 jun. 2010.

10. Receita Federal Brasileira. Subsecretaria de Tributação e Contencioso. Coordenação-Geral de Estudos, Previsão e Análise. Carga tributária no Brasil 2008 - Análise por tributos e bases de incidência. Brasilia, 2008b 
11. Secretaria da Receita Federal. Exportações segundo as principais

mercadorias. Brasília, [200-?]. Disponível em:

<http://www.receita.fazenda.gov.br/>. Acesso em: 10 dez. 2009b

12. BRAZIL EXPORT. Editorial. Carga Tributária: O freio do Brasil. Rio de Janeiro, Ano 39. 380 ed., jul./agos., 2009

13. CASTRO, José Augusto de. Exportação: aspectos práticos e operacionais. São Paulo: Aduaneiras, 2007

14. CHIMENTI, R. C. Direito Tributário. 9. ed. São Paulo: Saraiva, 2006

15. CHUDNOVSKY,D. La competitividad internacional: principales questiones: conceptuales y metodologica. [S.1.]: CEIPOS, 1990. Mimeo.

16. CENTRAL INTELLIGENCE AGENCY. [S.1.: CIA, 200-?]. Disponível em: <https://www.cia.gov/library/publications/the-world-factbook/geos/br.html\#top>. Acesso em: 10 dez. 2009.

17. CONFEDERAÇÃO NACIONAL DA INDÚSTRIA. Pesquisa: os problema da empresa exportadora brasileira. Brasília: CNI, , 2008

18. FISCONTEX. Alíquotas estaduais do ICMS. [S.1.: FISCONTEX, 200-?].

Disponível em :

<http://www.fiscontex.com.br/legislacao/ICMS/aliquotainternaicms.htm>. Acesso em: 14 jun. 2010.

19. FREITAS, Vladimir Passos (Coordenador). Importação e exportação no Direito Brasileiro. São Paulo: Editora Revista dos Tribunais, 2006.

20. GARCIA, Luiz Martins. Exportar: rotinas e procedimentos, incentivos e formação de preços. 7. ed. São Paulo: Aduaneiras, 2001.

21. GIL, Antonio Carlos. Como elaborar projetos de pesquisa. 4 ed.. São Paulo: Atlas, 2002.

22. GOUVÊA, Marcus de Freitas. A extrafiscalidade no Direito Tributário e suas classificações . Jus Navigandi, Teresina, ano 11, n. 1226, 9 nov. 2006. Disponível em: <http://jus2.uol.com.br/doutrina/texto.asp?id=9151>. Acesso em: 10 jun. 2010.

23. HARADA, Kiyoshi. IPI - Direito a crédito como decorrência do princípio da nãocumulatividade . Jus Navigandi, Teresina, ano 7, n. 66, jun. 2003. Disponível em: <http://jus2.uol.com.br/doutrina/texto.asp?id=4130>. Acesso em: 13 jun. 2010.

24. INTERNACIONAL CHAMBER OF COMMERCE-, [S.1.: ICC, 200-?]. INCOTERMS - Internacional Commercial Terms. Paris. 2000

25. KEEDI, Samir. ABC do comércio exterior: abrindo as primeiras páginas. 3. ed. São Paulo: Aduaneiras, 2008.

26. Logística de transporte internacional: veículo prático de competitividade. 1. ed. São Paulo: Aduaneiras, 2001.

27. LOPEZ, José Manoel Cortiñas. Os custos logísticos do comércio exterior brasileiro. São Paulo: Aduaneiras, 2000.

28. LOPEZ, José Manuel; GAMA, Marilza. Comércio Exterior Competitivo. 3. ed. São Paulo: Aduaneiras, 2007. 
29. MACHADO, Fernando Bicca. A sistemática da não-cumulatividade da contribuição ao PIS e da COFINS . Jus Navigandi, Teresina, ano 10, n. 860, 10 nov. 2005.

Disponível em: <http://jus2.uol.com.br/doutrina/texto.asp?id=7513>. Acesso em: 09 jun. 2010.

30. MACHADO, Hugo de Brito. Curso de Direito Tributário. 24 ed. São Paulo: Malheiros, 2004.

31. MAIA, Lerson Fernando dos Santos; OLIVEIRA, Marcus Vinicius de Faria. Trabalhos Acadêmicos: princípios, normas e técnicas. CEFET/RN. Natal, 2005.

32. MALUF, Sâmia Nagib. Administrando o comércio exterior do Brasil. São Paulo: Aduaneiras, 2000.

33. MAYER, Beatrice M. Z. F. Influência do drawback no preço de exportação no setor moveleiro de São Bento do Sul 2006. 203 f. Dissertação (Mestrado em Administração) Curso de Pós-Graduação em Administração, Universidade Federal de Santa Catarina, Florianópolis, 2006.

34. MELLO, José Eduardo Soares de. LIPPO, Luiz Francisco. A não-cumulatividade tributária. 2. ed. São Paulo: Dialética, 2004.

35. MINERVINI, Nicola. Exportar: competitividade e internacionalização. São Paulo: Makron Books, 1997.

36. MINERVINI, Nicola. O Exportador. 4. ed. São Paulo: Makron Books, 2008.

37. RATTI, Bruno. Comércio internacional e câmbio. 10. ed. São Paulo: Aduaneiras, 2000 .

38. SANTOS, Milton. Por uma outra globalização: do pensamento único à consciência universal. 15 ed. Rio de Janeiro: Record, 2008

39. WERNECK, Paulo L. . Imposto de Importação de Exportação \& Outros Gravames Aduaneiros. 1. ed. Rio de Janeiro: Freitas Bastos, 2007. 


\section{APÊNDICE A- PREÇO EXW}

Preço EXW - Ex Work

Componentes do preço no Mercado Interno

Preço do Mercado Interno sem IPI

Deduções

$(-) \quad$ ICMS:

(-) COFINS:

(-) PIS:

(-) Outros Tributos:

(-) Lucro de mercado Interno:

(-) Embalagem de Mercado Interno:

(-) Comissão de vendedor no mercado interno:

(-) Despesas de propaganda no mercado interno:

(-) Despesas de distribuição de mercado interno:

(-) Outras despesas que não incidirão no mercado externo:

\section{Total das Deduções}

(=) SUBTOTAL - Componentes do Preço de Mercado Interno:

Componentes do preço na Exportação

Inclusões
$(+)$ Embalagens:
$(+)$ Desembaraço Aduaneiro na Exportação
(+) Outras despesas:

Total das I

(=) SUBTOTAL - Componentes do Preço na Exportação:

(=) CUSTO TOTAL:

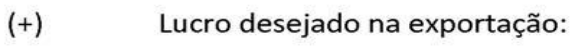

Preço EXW em moeda nacional:

Taxa Cambial:

$\mathrm{R} \$$

$\mathrm{R} \$$

$\mathrm{RS}$

$\mathrm{RS}$

Dedução/Inclusão Valor Total

$\mathrm{R} \$$

$\mathrm{R} \$$

$\mathrm{R} \$$

$\mathrm{RS}$

$\mathrm{R} \$$

$\mathrm{R} \$$

$\mathrm{R} \$$

$\mathrm{R} \$$

$\mathrm{R} \$$

$\mathrm{R} \$$

$\mathrm{R} \$$

$\mathrm{R} \$$

$\mathrm{R} \$$

RS

$\mathrm{R} \$$

$\mathrm{RS}$

$\mathrm{RS}$

$\mathrm{RS}$

$\mathrm{R} \$$

$\mathrm{RS}$

$\%$

$\mathrm{R} \$$

$\mathrm{R} \$$

$\mathrm{R} \$$

US\$

(=) preço EXW moeda estrangeira:

Fonte: Adaptado de BRASIL (2010) 


\section{APÊNDICE B- PREÇO FCA}

Preço FCA - Free Carrier

Componentes do preço no Mercado Interno

Dedução/Inclusão Valor Total

$\mathrm{R} \$$

Preço do Mercado Interno sem IPI

$\mathrm{R} \$$

Deduções

(-) ICMS:

(-) COFINS:

(-) PIS:

(-) Outros Tributos:

(-) Lucro de mercado Interno:

(-) Embalagem de Mercado Interno:

(-) Comissão de vendedor no mercado interno:

(-) Despesas de propaganda no mercado interno:

(-) Despesas de distribuição de mercado interno:

(-) Outras despesas que não incidirão no mercado externo:

Total das Deduções

(=) SUBTOTAL - Componentes do Preço de Mercado Interno:

Componentes do preço na Exportação

Inclusões

(+) Embalagens:

(+) Carregamento:

(+) Transporte Interno:

$(+)$ Desembaraço aduaneiro na exportação:

$(+)$ Despesas portuárias:

$(+)$ Despesas aeroportuárias:

$(+) \quad$ Outras despesas:

Total das I

(=) SUBTOTAL - Componentes do Preço na Exportação: RS

(=) CUSTO TOTAL:

$\% \quad \mathrm{R} \$$

Preço FCA em moeda nacional:

$\mathrm{R} \$$

Taxa Cambial:

$\mathrm{R} \$$

$\mathrm{R} \$$

(=) preço FCA moeda estrangeira:

Fonte: Adaptado de BRASIL (2010) 


\section{APÊNDICE C- PREÇO CIF}

Preço CIF - Cost, Insurance and Freight

Componentes do preço no Mercado Interno

Dedução/Inclusão Valor Total

$\mathrm{R} \$$

$\mathrm{R} \$$

Preço do Mercado Interno sem IPI

$\mathrm{RS}$

Deduções

$(-) \quad$ ICMS:

$(-)$ COFINS:

$(-) \quad$ PIS:

(-) Outros Tributos:

(-) Lucro de mercado Interno:

(-) Embalagem de Mercado Interno:

(-) Comissão de vendedor no mercado interno:

(-) Despesas de propaganda no mercado interno:

(-) Despesas de distribuição de mercado interno:

(-) Outras despesas que não incidirão no mercado externo:

\section{Total das Deduções}

(=) SUBTOTAL - Componentes do Preço de Mercado Interno:

Componentes do preço na Exportação Inclusões

$(+)$ Embalagens:

(+) Carregamento:

(+) Transporte Interno:

$(+)$ Desembaraço aduaneiro na exportação:

$(+)$ Despesas portuárias:

$(+)$ Despesas aeroportuárias:

$(+) \quad$ Aluguel do container:

$(+)$ Transporte e seguro do container até o costado do navio:

Carga, descarga e estadia do container:

$(+) \quad$ Capatazia e taxas portuárias:

$(+) \quad$ Seguro Internacional

$(+) \quad$ Frete Internacional

$(+) \quad$ Outras despesas:$$
\text { Outr }
$$

(=) SUBTOTAL - Componentes do Preço na Exportação:

(=) CUSTO TOTAL:

Lucro desejado na exportação:

$\%$

$\mathrm{R} \$$

Preço CIF em moeda nacional:

$\mathrm{R} \$$

$\mathrm{R} \$$

Taxa Cambial:

$\mathrm{R} \$$

US\$

(=) preço CIF moeda estrangeira:

US\$

Fonte: Adaptado de BRASIL (2010) 


\section{APÊNDICE D- PREÇO CIP}

Preço CIP - Carriage and Insurance Paid to

Componentes do preço no Mercado Interno

Dedução/Inclusão Valor Total

RS

$\mathrm{RS}$

Preço do Mercado Interno sem IPI

Deduções

(-) ICMS:

(-) COFINS:

(-) PIS:

(-) Outros Tributos:

(-) Lucro de mercado Interno:

(-) Embalagem de Mercado Interno:

(-) Comissão de vendedor no mercado interno:

(-) Despesas de propaganda no mercado interno:

(-) Despesas de distribuição de mercado interno:

(-) Outras despesas que não incidirão no mercado externo:

Total das Deduções

(=) SUBTOTAL - Componentes do Preço de Mercado Interno:

Componentes do preço na Exportação Inclusões

(+) Embalagens:

(+) Carregamento:

(+) Transporte Interno:

(+) Desembaraço aduaneiro na exportação:

(+) Despesas portuárias:

(+) Despesas aeroportuárias:

(+) Aluguel do container:

(+) Transporte e seguro do container até o costado do navio:

(+) Carga, descarga e estadia do container:

(+) Capatazia e taxas portuárias:

(+) Seguro Internacional:

(+) Frete Internacional:

(+) Outras despesas:

\section{Total das I}

(=) SUBTOTAL - Componentes do Preço na Exportação:

(=) CUSTO TOTAL:

(+) Lucro desejado na exportação:

Preço CIP em moeda nacional:

(=) preço CIP moeda estrangeira:

Fonte: Adaptado de BRASIL (2010) 


\section{APÊNDICE E- PREÇO DDP}

Preço DDP - Delivered Dut Paid

Componentes do preço no Mercado Interno

Dedução/Inclusão Valor Total RS

Preço do Mercado Interno sem IPI

Deduções

(-) ICMS:

(-) COFINS:

(-) PIS:

(-) Outros Tributos:

(-) Lucro de mercado Interno:

(-) Embalagem de Mercado Interno:

(-) Comissão de vendedor no mercado interno:

(-) Despesas de propaganda no mercado interno:

(-) Despesas de distribuição de mercado interno:

(-) Outras despesas que não incidirão no mercado externo: Total das Deduções

(=) SUBTOTAL - Componentes do Preço de Mercado Interno:

Componentes do preço na Exportação

S\$

$\mathrm{RS}$

$\mathrm{RS}$

$\mathrm{R} \$$

$\mathrm{RS}$

$\mathrm{R} S$

$\mathrm{RS}$

$\mathrm{R} \$$

$\mathrm{R} S$

$\mathrm{RS}$

$\mathrm{RS}$

$\mathrm{RS}$

$\mathrm{R} \$$

$\mathrm{R} \$$

Inclusões

(+) Embalagens:

(+) Carregamento:

(+) Transporte Interno:

(+) Desembaraço aduaneiro na exportação:

(+) Despesas portuárias:

(+) Despesas aeroportuárias:

(+) Aluguel do container:

(+) Transporte e seguro do container até o costado do navio:

(+) Carga, descarga e estadia do container:

(+) Capatazia e taxas portuárias:

(+) Seguro Internacional:

(+) Frete Internacional:

(+) Descarregamento da mercadoria no porto de destino:

(+) Transporte interno no país de destino:

(+) Desembaraço aduaneiro na importação:

(+) Outras despesas:

Total das I

(=) SUBTOTAL - Componentes do Preço na Exportação:

(=) CUSTO TOTAL:

(+) Lucro desejado na exportação:

$\mathrm{R} \$$

Preço DDP em moeda nacional:

$\mathrm{R} \$$

$\mathrm{RS}$

Taxa Cambial:

$\mathrm{R} \$$

US\$

(=) preço DDP moeda estrangeira:

US\$

Fonte: Adaptado de BRASIL (2010) 